Board of Governors of the Federal Reserve System

International Finance Discussion Papers

Number 561

August 1996

INFLATION-ADJUSTED POTENTIAL OUTPUT

\author{
Jane T. Haltmaier
}

NOTE: International Finance Discussion Papers are preliminary materials circulated to stimulate discussion and critical comment. References in publications to International Finance Discussion Papers (other than an acknowledgment that the writer has had access to unpublished material) should be cleared with the author or authors. 


\begin{abstract}
This paper estimates potential output for seven countries using a multivariate version of the Hodrick-Prescott filter in which observations on inflation are used to help separate trend from cyclical movements in output. The potential series are estimated first on an aggregate basis, and then by disaggregating output into three major components: labor productivity, the employment-population ratio, and population. Potential levels of productivity and the employment-population ratios are calculated using the multivariate filter and combined with actual population to derive an alternative, "disaggregated" estimate of potential. The method is then applied to forecasting potential growth.
\end{abstract}




\title{
Inflation-Adjusted Potential Output
}

\author{
Jane Haltmaier
}

\section{Introduction}

Measures of potential output, both levels and growth rates, are quite important as guides for macroeconomic policymakers. This is especially the case for monetary authorities trying to determine the appropriate stance of monetary policy. At ieast in theory, inflation should decelerate when output is below potential and vice versa. Thus, expansionary monetary policy should not run the risk of resulting in an increase in inflation as long as output is below potential. Similarly, a central bank that is trying to engineer a reduction in the inflation rate will need to pursue a contractionary policy if output is at or above potential. Thus, knowledge of the current output gap is critical.

Given the sizable lags with which monetary policy affects the economy, it is also important to have an estimate of the rate at which potential output is growing. For instance, the British Chancellor recently suggested that monetary policy could afford to be a little looser because of his belief that the rate of potential output growth had increased, suggesting that a higher rate of growth of actual output than in the recent past would not be inflationary. Estimated potential output growth is also a key element in the determination of monetary

The author is an Economist in the Division of International Finance, Board of Governors of the Federal Reserve System. This paper represents the views of the author and should not be interpreted as reflecting the views of the Board of Governors of the Federal Reserve System or other members of its staff. 
targets in those countries in which monetary aggregates are used as principal policy guides. In a monetary rule regime, a constant rate of inflation can theoretically be achieved by setting the rate of money supply growth equal to the targeted inflation rate, plus the rate of potential output growth, minus the expected rate of change of velocity. This is in fact the method used by the German Bundesbank in setting its money growth targets. In other countries where money supply rules are not the primary guide to policy, the rate of growth of potential output is still taken into consideration in determining the non-inflationary rate of actual output growth. However, despite its importance, potential output is probably even more difficult to estimate accurately than the related concept of the NAIRU.

There are basically two types of approaches to estimating potential output. ${ }^{2}$ One is to use some type of filter to separate trend from cyclical components in the aggregate output data. An alternative method is the so-called "production-function" approach, which decomposes potential output into its technology, labor, and capital components, and estimates full-employment levels of each. Each approach has both advantages and disadvantages.

A commonly-used filtering technique is that introduced by Hodrick and Prescott (1980). The Hodrick-Prescott (HP) filter smooths actual output so that potential output is a weighted average of past and future actual values. Although this technique can be very useful, it also has several drawbacks. For instance, it suffers from an "endpoint" problem that occurs because, although the smoothed series is calculated as a centered weighted average of actual observations throughout most of the period analyzed, it depends only on

\footnotetext{
${ }^{2}$ Laxton and Tetlow (1992) provide a comprehensive summary of much of the literature in this area.
} 
past values at the end (and on furure values at the beginning). In addition, this method will usually produce a potential output series that approximates the average level of actual output over time, that is, the estimated output gap will generally have an average value close to zero. This technique thus does not allow for the possibility that output may be above potential more often than it is below or vice versa. In addition, output gaps derived from the HP filter will not necessarily be consistent with the concurrent behavior of inflation.

Kuttner (1994) addresses the latter problem by using a Kalman filter to derive estimates of potential output for the United States that are consistent with observed inflation rates. However, this approach assumes that the potential output growth rate follows a random walk, which may be true for the United States, but does not appear to be the case for most of the foreign industrial countries. An alternative method, developed by Laxton and Tetlow (1992) uses an expanded version of the HP filter, which does allow mean growth rates to vary over time, to adjust gaps for inflation. This technique is termed a multivariate (MV) filter.

The production function method should in theory produce an estimate of potential output that is related to the actual behavior of inflation, since employment, a key component, can be adjusted to its full-employment level using estimates of the NAIRU that are compatible with inflation data. This method generally also requires information on capital stock and labor force participation, as well as some technique for adjusting the latter to its "fullemployment" level. (The capital stock is generally assumed to be either fully utilized or utilized at its "average" level at potential.) Total factor productivity must also be adjusted foi cyclical variation. The OECD produces potential output estimates for most of its member 
countries using a production function approach in which the HP filter is used to adjust total factor productivity, with the same advantages and disadvantages that apply to adjusting total output. However, one advantage to the production function approach is that, because it has a structural as well as a time series element, it is somewhat more useful for extrapolating potential growth rates than the aggregate filtering techniques.

In fact, the ability to project potential output growth, at least over a forecast horizon of a couple of years, would appear to be critical for such measures to really be useful for policymakers. Although it may be important for some purposes to know the size of historical output gaps, it is clearly much more important to know the size of the current gap as well as how it is likely to change over the relevant forecast period. Simply adjusting the output gap so that it is consistent with the current behavior of inflation does not really give us much more information than simply looking at inflation itself. It is only if our estimates of potential output can give us some insight into how the gap is likely to change given the current and projected behavior of actual output that we have really gained anything.

This paper combines elements of the MV filter and the production function methods in an attempt to produce estimates of potential output for the G-7 countries that are both adjusted for inflation and able to be extrapolated. ${ }^{3}$ The method is first applied to aggregate GDP, and then to a decomposition of GDP into its labor productivity and labor components (a partial production-function approach). The latter is represented by the employmentpopulation ratio, as working-age population is assumed not to have a cyclical component.

3 Western Germany was used in place of unified Germany because of the lack of unified data before 1991 . 
Potential output growth can then be extrapolated by using actual projections of working-age population (one variable for which we do have fairly accurate forecasts), as well as assumptions about trend productivity growth and the full-employment level of the employment-population ratio. The disaggregated method thus allows us to make use of a much larger information set in forecasting than does the aggregate approach

Section II describes the technique in more detail, Section III presents the estimation results, and Section IV uses the estimates to project potential output growth over the next two years. Section $\mathrm{V}$ concludes with some suggestions for further analysis.

\section{The Multivariate Filter}

The Hodrick-Prescott (HP) filter calculates a smoothed series by minimizing the expression:

$$
\mathrm{X}=\sum_{t=1}^{T}\left(Y_{t}-\bar{Y}_{t}\right)^{2}+\lambda \sum_{t=2}^{T-1}\left[\left(\bar{Y}_{t+1}-\bar{Y}_{t}\right)-\left(\bar{Y}_{t}-\bar{Y}_{t-1}\right)\right]^{2}
$$

where $Y$ is actual output and $\bar{Y}$ is the smoothed output series. The smoothed series is thus calculated by trading off deviations between the actual and smoothed series (the first term) for variations in the growth rate of the smoothed series from one period to the next (the second term). The parameter $\lambda$ determines how closely the smoothed series follows the actual; a higher value of $\lambda$ will produce a smoother series, while a lower value will produce one that is closer to the actual. The choice of $\lambda$, although important to the final result, is somewhat arbitrary, although it has been suggested that it should represent the ratio of the variance of the cycle to the variance of the trend. The value most often used for quarterly data is 1600 , as done by the original researchers, and this value was also used here. 
The multivariate filter augments the above expression with an output-inflation equation, and then calculates a potential output series that minimizes the entire expression. In the equation used here, the current inflation rate depends primarily on past inflation and the lagged output gap. Changes in the exchange rate and, where applicable, the value-added tax, are included as additional explanatory variables for inflation. The inflation equation is:

$$
\Pi_{t}=A(L) \Pi_{t-1}+B(L) Z_{t}+C(L)\left(Y_{t-1}-\bar{Y}_{t-1}\right)+\epsilon_{t}
$$

where $\Pi$ is the quarterly change in the $\log$ of the price level, and $Z$ represents the vector of other variables that affect the current inflation rate. The weights in $A(L)$ are assumed to sum to 1 . The expression to be minimized is:

$$
\mathrm{X}=\sum_{t=1}^{T}\left(Y_{t}-\bar{Y}_{t}\right)^{2}+\lambda \sum_{t=2}^{T-1}\left[\left(\bar{Y}_{t+1}-\bar{Y}_{t}\right)-\left(\bar{Y}_{t}-\bar{Y}_{t-1}\right)\right]^{2}+\alpha \sum_{t+2}^{T-1} \epsilon_{t}^{2}
$$

where $\alpha$ is the weighting factor for the inflation expression. Rearranging (2) and substituting into (3), the expression to be minimized becomes:

$$
\mathrm{X}=\sum_{t=1}^{T}\left(Y_{t}-\bar{Y}_{t}\right)^{2}+\lambda \sum_{t=2}^{T-1}\left[\left(\bar{Y}_{t+1}-\bar{Y}_{t}\right)-\left(\bar{Y}_{t}-\bar{Y}_{t-1}\right)\right]^{2}+\alpha \sum_{t=1}^{T}\left[\dot{\mathrm{I}}-C(L)\left(Y_{t-1}-\bar{Y}_{t-1}\right)\right]^{2}
$$

where $\dot{\Pi}$ is the acceleration in inflation relative to its past values that is not due to changes in other variables such as the exchange rate or taxes. The resulting potential output series will thus differ from that obtained from an application of the simple HP filter to the extent that it explains more of the change in inflation. It will, however, still be subject to a smoothness 
constraint, meaning that sudden changes from acceleration to deceleration in inflation will not be allowed to produce overly sharp swings in the rate of growth of potential output.

There are two problems with this technique that need to be addressed before it can be applied empirically. The first is that estimates of the parameters of (2) are required to calculate the potential output series, but estimates of the potential output series are also needed to calculate the parameters. In theory, they could all be estimated jointly, but in practice, this is very difficult. ${ }^{4}$ The solution used here was a two-step procedure. First, an initial potential output series was obtained using the traditional HP filter, and this series was used to estimate equation (2). The resulting parameters were then used to minimize (4). As a check, the new estimates were then used to reestimate the inflation equation, but the changes were so trivial that no further iterations were done.

The second problem is the choice of $\alpha$, the weight placed on the inflation component. Intuitively, it should be apparent why such a weight is needed. The inflation acceleration term, measured as the unexplained part of the quarterly change in the log of the price level, is of an order of magnitude similar to the change in the trend, which is weighted by a factor of 1600 . Unweighted, the inflation term will have no impact on the minimization problem. However, there is even less theory to guide the choice of $\alpha$ than there is in choosing $\lambda$. Several different values were tried, ranging from 200 to 800 . Although the resulting differences were not large, 400 seemed to produce the most sensible results, and so that was the value used for the main results. Some further discussion of this issue, along with results obtained using $\alpha$ 's of 200 and 800 are contained in the Appendix.

\footnotetext{
${ }^{4}$ I would hesitate to say that it is impossible, but it is certainly beyond the scope of this paper.
} 
The disaggregated inflation equation decomposes the difference between actual and potential output into two components: the gap between actual and trend labor productivity and the gap between the actual and trend employment-to-working-age population ratio. (Working-age population is assumed to be invariant to the cycle.) Variations in the unemployment rate and the participation rate, both of which are cyclical, are thus consolidated into the employment-population ratio. While it would probably be more satisfactory to treat these two elements separately, that would produce an expression that would be too unwieldy. The disaggregated inflation equation, then, is:

$$
\Pi_{t}=A(L) \Pi_{t-1}+B(L) Z_{t}+D(L)\left(P_{t-1}-\bar{P}_{t-1}\right)+E(L)\left(R_{t-1}-\bar{R}_{t-1}\right)+\epsilon_{t}
$$

where $\mathrm{P}$ is labor productivity and $\mathrm{R}$ is the employment-population ratio. The expression to be minimized is:

(6)

$$
\begin{aligned}
\mathrm{X}=\sum_{t=1}^{T}\left(P_{t}-\bar{P}_{t}\right)^{2} & +\sum_{t=1}^{T}\left(R_{t}-\bar{R}_{t}\right)^{2}+\lambda \sum_{t=2}^{T-1}\left[\left(\bar{P}_{t+1}-\bar{P}_{t}\right)-\left(\bar{P}_{t}-\bar{P}_{t-1}\right)\right]^{2} \\
& +\lambda \sum_{t=2}^{T-1}\left[\left(\bar{R}_{t+1}-\bar{R}_{t}\right)-\left(\bar{R}_{t}-\bar{R}_{t-1}\right)\right]^{2} \\
& +\alpha \sum_{t=1}^{T}\left[\dot{\mathrm{I}}-D(L)\left(P_{t-1}-\bar{P}_{t-1}\right)-E(L)\left(R_{t-1}-\bar{R}_{t-1}\right)\right]^{2}
\end{aligned}
$$

\section{Empirical Results}

The HP filter was used to calculate potential output series for western Germany, France, Italy, the United Kingdom, Canada, Japan, and the United States, for the period 1968 through 1995. The resulting series were used to estimate inflation equations from 1970 
through 1993, thus excluding the periods for which the estimates of potential output are the most uncertain. ${ }^{5}$

As indicated above, in addition to the "gap" terms, the estimated inflation equations include past lags of inflation, with the weights constrained to sum to one, as well as current and/or lagged changes in the (log of) the exchange rate and oil prices, and changes in the value-added tax. ${ }^{6}$ The German equation also included a dummy for the period of unification. The precise lags used vary from one equation to another, since the timing of the impact of exchange rate and oil price changes appear to differ across countries. The equations all included one and two lags of the gap terms.

\section{Aggregate Equations}

The results from the estimation of the aggregate inflation equations are summarized in the following table. Seven of the fourteen GAP variables were significant at least at the 5 percent level, and several others were close. Generally the coefficient on the first lag was positive and that on the second was smaller and negative, suggesting a "speed effect" from changes in the output gap. In fact, the speed effect, measured as the coefficient on the second gap term (sign reversed), is generally larger than the level effect (the sum of the two coefficients). The main exception is France, where both coefficients are positive and neither are significant.

\footnotetext{
5 The one exception was the Japanese equation, which was estimated over the period 1975-1993. The reason is that the $1973-74$ period contains an episode of very high inflation along with a very high output gap. This produces an extremely large gap coefficient that did not seem to be representative of the rest of the sample.
}

${ }^{6}$ The VAT change series were provided by Carol Bertaut and Deb Lindner. 


\begin{tabular}{|c|c|c|c|c|c|c|c|}
\hline \multicolumn{8}{|c|}{ Estimation Results for Aggregate Output Gap Equations } \\
\hline & Germany & France & Italy & U.K. & Canada & Japan & U.S. \\
\hline$\Pi_{-1}$ & $\begin{array}{l}.510^{* *} \\
(.096)\end{array}$ & $\begin{array}{l}.647^{* *} \\
(.097) \\
\end{array}$ & $\begin{array}{l}.703^{* *} \\
(.106)\end{array}$ & $\begin{array}{l}.657^{* *} \\
(.104)\end{array}$ & $\begin{array}{l}.595^{* *} \\
(.099)\end{array}$ & $\begin{array}{l}.622^{* *} \\
(.113)\end{array}$ & $\begin{array}{l}.560^{* *} \\
(.094)\end{array}$ \\
\hline$\Pi_{.2}$ & $\begin{array}{c}.105 \\
(.103)\end{array}$ & $\begin{array}{c}.176 \\
(.114) \\
\end{array}$ & $\begin{array}{c}.177 \\
(.127)\end{array}$ & $\begin{array}{l}.200^{*} \\
(.121)\end{array}$ & $\begin{array}{c}.158 \\
(.115)\end{array}$ & $\begin{array}{c}.138 \\
(.131) \\
\end{array}$ & $\begin{array}{c}-.051 \\
(.112) \\
\end{array}$ \\
\hline$\Pi_{.3}$ & $\begin{array}{l}.220^{*} \\
(.100)\end{array}$ & $\begin{array}{l}-.093 \\
(.119)\end{array}$ & $\begin{array}{l}.057^{*} \\
(.027)\end{array}$ & $\begin{array}{c}-.070 \\
(.120)\end{array}$ & $\begin{array}{c}.067 \\
(.114)\end{array}$ & $\begin{array}{l}.239 \\
\text { n.a. }\end{array}$ & $\begin{array}{l}.491 \\
\text { n.a. }\end{array}$ \\
\hline$\Pi_{\lrcorner}$ & $\begin{array}{l}.165 \\
\text { n.a. }\end{array}$ & $\begin{array}{l}.270 \\
\text { n.a. }\end{array}$ & $\begin{array}{l}.064 \\
\text { n.a. }\end{array}$ & $\begin{array}{l}.212 \\
\text { n.a. }\end{array}$ & $\begin{array}{l}.179 \\
\text { n.a. }\end{array}$ & n.a. & n.a. \\
\hline$\triangle \mathrm{VAT}$ & $\begin{array}{c}.002 \\
(.002) \\
\end{array}$ & $\begin{array}{l}.002^{*} \\
(.001) \\
\end{array}$ & $\begin{array}{r}.0002 \\
(0007) \\
\end{array}$ & $\begin{array}{l}.002^{*} \\
(.001)\end{array}$ & n.a. & $\begin{array}{l}.004^{*} \\
(.002)\end{array}$ & n.a. \\
\hline$\Delta \mathrm{EX}$ & $\begin{array}{c}-.031^{* *} \\
(.011)\end{array}$ & $\begin{array}{l}.006 \\
(.018)\end{array}$ & $\begin{array}{c}-.057^{*} \\
(.027) \\
\end{array}$ & $\begin{array}{c}.001 \\
(.028)\end{array}$ & $\begin{array}{r}-.002 \\
(.013)\end{array}$ & $\begin{array}{c}.010 \\
(.016) \\
\end{array}$ & $\begin{array}{c}-.002 \\
(.011)\end{array}$ \\
\hline$\Delta \mathrm{EX}_{.1}$ & n.a. & $\begin{array}{r}-.018 \\
(.017) \\
\end{array}$ & n.a. & $\begin{array}{c}-.026 \\
(.028)\end{array}$ & $\begin{array}{c}-.020 \\
(.014) \\
\end{array}$ & $\begin{array}{r}-.026 \\
(.018) \\
\end{array}$ & $\begin{array}{c}-.009 \\
(.011) \\
\end{array}$ \\
\hline$\Delta \mathrm{EX}_{.2}$ & n.a. & n.a. & n.a. & $\begin{array}{r}-.028 \\
(.028) \\
\end{array}$ & $\begin{array}{l}-.029 * \\
(.013) \\
\end{array}$ & n.a. & n.a. \\
\hline$\triangle P O$ & $\begin{array}{l}.005^{* *} \\
(.002) \\
\end{array}$ & $\begin{array}{l}.013^{* *} \\
(.003) \\
\end{array}$ & $\begin{array}{l}.011^{*} \\
(.006) \\
\end{array}$ & n.a. & $\begin{array}{l}-.002 \\
(.003) \\
\end{array}$ & $\begin{array}{c}.002 \\
(.006) \\
\end{array}$ & $\begin{array}{l}.010^{* *} \\
(.003)\end{array}$ \\
\hline$\Delta P O_{-1}$ & n.a. & $\begin{array}{c}.016 \\
(.073) \\
\end{array}$ & n.a. & n.a. & $\begin{array}{l}.011^{* *} \\
(.003)\end{array}$ & $\begin{array}{c}.008 \\
(.006) \\
\end{array}$ & n.a. \\
\hline $\mathrm{GAP}_{.1}$ & $\begin{array}{l}.088^{* *} \\
(.031)\end{array}$ & $\begin{array}{c}.016 \\
(.073) \\
\end{array}$ & $\begin{array}{l}.172^{*} \\
(.106)\end{array}$ & $\begin{array}{c}.145 \\
(.099)\end{array}$ & $\begin{array}{l}.120^{* *} \\
(.050)\end{array}$ & $\begin{array}{l}.301^{* *} \\
(.113)\end{array}$ & $\begin{array}{l}.161^{* *} \\
(.048)\end{array}$ \\
\hline $\mathrm{GAP}_{.2}$ & $\begin{array}{l}-.064^{*} \\
(.030) \\
\end{array}$ & $\begin{array}{c}.006 \\
(.072) \\
\end{array}$ & $\begin{array}{r}-.138 \\
(.097) \\
\end{array}$ & $\begin{array}{r}-.009 \\
(.095) \\
\end{array}$ & $\begin{array}{r}-.069 \\
(.050) \\
\end{array}$ & $\begin{array}{r}-.227 \\
(.113) \\
\end{array}$ & $\begin{array}{c}-.093^{*} \\
(.047) \\
\end{array}$ \\
\hline $\mathbf{R}^{2}$ & .85 & .93 & .90 & .82 & .89 & .83 & .89 \\
\hline
\end{tabular}

* Significant at the $1 \%$ level.

Significant at the $5 \%$ level.

n.a. $=$ not applicable

Charts 1 through 7 show output gaps obtained with both the HP filter and the

multivariate filter. Also included is the "inflation acceleration" term, calculated as the part of the current-period inflation rate that is not explained by either past inflation, changes in the VAT, or exchange rate or oil price movements. (Both the inflation acceleration and gap terms are plotted as four-quarter moving averages to show the trend more clearly.) As 
expected, the MV filter output gaps follow the pattern of inflation much more closely than the HP filter gaps. For example, the long period of disinflation in Western Germany in the 1980 's suggests that the output gap was more negative than the HP filter shows, while the period of inflation acceleration that followed suggests that the output gap was much narrower than the HP filter gap. In the current period, the downward trend in inflation suggests that the output gap is wider than the HP filter shows. Similar adjustments occur for the 1980's for the other European countries. For Canada, the differences between the two gap series tend to be somewhat smaller, although the pattern of inflation currently suggests that the output gap is close to zero rather than in the positive range as the HP filter series implies. The Japanese MV output gap series is currently closer to zero now than the simple HP filter series. For the United States, the MV filter series suggests that the output gap is close to zero, rather than in the positive range as indicated by the HP filter series.

\section{Disaggregated Approach}

One advantage to disaggregation, apart from possible differential impacts of inflation on the productivity and labor components, is simply that it allows incorporation of trends in working-age population growth and labor force participation, which may shift over time. The results from the estimation of the equations that break output into its productivity and labor components are shown in the following table. The coefficients on lagged inflation, the VAT, the oil price term, and the exchange rate are similar to those obtained using aggregate GDP. The coefficients on the gap terms in these equations are less often significant than those in the aggregate equations. This may be due to multicollinearity, since the productivity and employment gaps are generally correlated with one another. It is interesting that the 


\begin{tabular}{|c|c|c|c|c|c|c|c|}
\hline \multicolumn{8}{|c|}{ Estimation Results for Disaggregated Output Gap Equations } \\
\hline & Germany & France & Italy & U.K. & Canada & Japan & U.S. \\
\hline$\Pi_{-1}$ & $\begin{array}{l}.484^{* *} \\
(.097) \\
\end{array}$ & $\begin{array}{l}.656^{* *} \\
(.096) \\
\end{array}$ & $\begin{array}{l}.661^{* *} \\
(.104) \\
\end{array}$ & $\begin{array}{l}.654^{* *} \\
(.107)\end{array}$ & $\begin{array}{l}.599^{* *} \\
(.101) \\
\end{array}$ & $\begin{array}{l}.643^{* *} \\
(.116) \\
\end{array}$ & $\begin{array}{l}.506^{* *} \\
(.090) \\
\end{array}$ \\
\hline$\Pi_{-2}$ & $\begin{array}{c}.107 \\
(.104) \\
\end{array}$ & $\begin{array}{c}.173 \\
(.112) \\
\end{array}$ & $\begin{array}{c}.116 \\
(.130) \\
\end{array}$ & $\begin{array}{l}.203^{*} \\
(.124) \\
\end{array}$ & $\begin{array}{c}.156 \\
(.116) \\
\end{array}$ & $\begin{array}{c}.138 \\
(.133) \\
\end{array}$ & $\begin{array}{r}.019 \\
(.105)\end{array}$ \\
\hline$\Pi_{.3}$ & $\begin{array}{l}.227^{*} \\
(.100) \\
\end{array}$ & $\begin{array}{l}-.115 \\
(.118) \\
\end{array}$ & $\begin{array}{c}.133 \\
(.124) \\
\end{array}$ & $\begin{array}{l}-.068 \\
(.121) \\
\end{array}$ & $\begin{array}{c}.069 \\
(.118)\end{array}$ & $\begin{array}{l}.219 \\
\text { n.a. }\end{array}$ & $\begin{array}{l}.475 \\
\text { n.a. }\end{array}$ \\
\hline$\Pi$ & $\begin{array}{l}.182 \\
\text { n.a. }\end{array}$ & $\begin{array}{l}.286 \\
\text { n.a. }\end{array}$ & $\begin{array}{l}.090 \\
\text { n.a. }\end{array}$ & $\begin{array}{l}.211 \\
\text { n.a. }\end{array}$ & $\begin{array}{l}.176 \\
\text { n.a. }\end{array}$ & n.a. & n.a. \\
\hline$\triangle \mathrm{VAT}$ & $\begin{array}{c}.002 \\
(.002) \\
\end{array}$ & $\begin{array}{l}.003^{* *} \\
(.001) \\
\end{array}$ & $\begin{array}{c}.000 \\
(0006) \\
\end{array}$ & $\begin{array}{l}.002^{*} \\
(.001) \\
\end{array}$ & n.a. & $\begin{array}{l}.004^{*} \\
(.002) \\
\end{array}$ & n.a. \\
\hline$\Delta \mathrm{EX}$ & $\begin{array}{c}-.032 * * \\
(.011)\end{array}$ & $\begin{array}{c}.009 \\
(.018)\end{array}$ & $\begin{array}{l}-.044^{*} \\
(.027)\end{array}$ & $\begin{array}{c}.002 \\
(.029) \\
\end{array}$ & $\begin{array}{c}-.004 \\
(.014) \\
\end{array}$ & $\begin{array}{r}-.002 \\
(.015) \\
\end{array}$ & $\begin{array}{l}-.008 \\
(.011) \\
\end{array}$ \\
\hline$\Delta \mathrm{EX}_{-1}$ & n.a. & $\begin{array}{r}-.020 \\
(.017) \\
\end{array}$ & n.a. & $\begin{array}{l}-.024 \\
(.029) \\
\end{array}$ & $\begin{array}{c}-.021 \\
(.015)\end{array}$ & n.a. & $\begin{array}{l}-.005 \\
(.011) \\
\end{array}$ \\
\hline$\Delta \mathrm{EX}_{.2}$ & n.a. & n.a. & n.a. & $\begin{array}{r}-.026 \\
(.029) \\
\end{array}$ & $\begin{array}{l}-.029 * \\
(.013) \\
\end{array}$ & n.a. & $\begin{array}{r}-.015 \\
(.010) \\
\end{array}$ \\
\hline$\triangle \mathrm{PO}$ & $\begin{array}{l}.005^{* *} \\
(.002)\end{array}$ & $\begin{array}{l}.013^{* *} \\
(.003)\end{array}$ & $\begin{array}{l}.012^{*} \\
(.006)\end{array}$ & n.a. & $\begin{array}{c}-.002 \\
(.003)\end{array}$ & $\begin{array}{c}.005 \\
(.006)\end{array}$ & $\begin{array}{l}.011^{*} \\
(.003)\end{array}$ \\
\hline$\Delta \mathrm{PO}_{.1}$ & n.a. & n.a. & $\begin{array}{l}.018^{* * *} \\
(.006) \\
\end{array}$ & n.a. & $\begin{array}{l}.011^{* *} \\
(.003) \\
\end{array}$ & $\begin{array}{c}.009 \\
(.006) \\
\end{array}$ & n.a. \\
\hline GAPE $_{.1}^{1}$ & $\begin{array}{l}.253^{*} \\
(.162) \\
\end{array}$ & $\begin{array}{c}.107 \\
(.093) \\
\end{array}$ & $\begin{array}{l}.250^{*} \\
(.152) \\
\end{array}$ & $\begin{array}{c}.142 \\
(.306) \\
\end{array}$ & $\begin{array}{r}.124 \\
(.085) \\
\end{array}$ & $\begin{array}{c}.411 \\
(.277) \\
\end{array}$ & $\begin{array}{l}.440^{* *} \\
(.095) \\
\end{array}$ \\
\hline GAPE $_{.2}$ & $\begin{array}{r}-.192 \\
(.158) \\
\end{array}$ & $\begin{array}{c}-.039 \\
(.084) \\
\end{array}$ & $\begin{array}{c}-.250^{*} \\
\text { n.a. }\end{array}$ & $\begin{array}{r}-.042 \\
(.300) \\
\end{array}$ & $\begin{array}{r}-.062 \\
(.080) \\
\end{array}$ & $\begin{array}{r}-.236 \\
(.261) \\
\end{array}$ & $\begin{array}{c}-.401 * * \\
(.091) \\
\end{array}$ \\
\hline $\operatorname{GAPP}_{-1}^{2}$ & $\begin{array}{c}.073^{*} \\
(.040) \\
\end{array}$ & $\begin{array}{c}.000 \\
(.070) \\
\end{array}$ & $\begin{array}{l}.158^{*} \\
(.092) \\
\end{array}$ & $\begin{array}{l}.145 \\
(.104)\end{array}$ & $\begin{array}{l}.123^{*} \\
(.063) \\
\end{array}$ & $\begin{array}{l}.271^{*} \\
(.116) \\
\end{array}$ & $\begin{array}{c}.049 \\
(.046) \\
\end{array}$ \\
\hline GAPP $_{-2}$ & $\begin{array}{c}-.067^{*} \\
(.036) \\
\end{array}$ & $\begin{array}{r}-.000 \\
(.070) \\
\end{array}$ & $\begin{array}{l}-.158^{*} \\
\text { n.a. }\end{array}$ & $\begin{array}{c}.010 \\
(.105) \\
\end{array}$ & $\begin{array}{r}-.100 \\
(.070) \\
\end{array}$ & $\begin{array}{l}-.224^{*} \\
(.124) \\
\end{array}$ & $\begin{array}{r}-.049 \\
(.046) \\
\end{array}$ \\
\hline $\mathrm{R}^{2}$ & .86 & .93 & .90 & .81 & .89 & .82 & .91 \\
\hline
\end{tabular}

1. Employment gap. 2. Productivity Gap *Significant at the $1 \%$ level. "Significant at the $5 \%$ level. 
"productivity gap" term is significant more often than the "employment gap" term, suggesting that only adjusting labor market data to reflect inflation, as in the production function approach, may not be sufficient.

Charts 8 through 14 show the inflation-adjusted gaps for both the aggregate and disaggregated series. Although most of the differences are fairly minor, there are some rather large discrepancies. Probably the most notable is for Germany in the late 1980's, when the aggregate series shows a slightly negative output gap, while the disaggregated shows a fairly substantial positive gap. As chart 15 shows, the difference is in large part due to the sizable swings in working-age population growth experienced by western Germany over this period. In particular, the very low rate of population growth in the late 1980's leads the disaggregated approach to show much slower potential growth than the aggregate method. As shown in charts 16 through 21 , such swings in population growth have also occurred in most other countries, suggesting that an aggregate approach may well miss some important changes in potential growth. One noteworthy example is the projected drop in Japanese working-age population for 1996 and 1997, which may limit Japanese potential growth over that period.

\section{Forecasting Potential Growth}

As noted earlier, estimation of the current and near-term rate of potential growth is probably at least as important for policy as estimation of the current gap. Estimated potential growth is an explicit component of the Bundesbank's money supply growth target, and is taken into account, at least implicitly, in many other countries. In addition, if speed effects exist, which they appear to do for several countries, changes in the gap (the difference 
between actual and potential growth) may be as important as the level in the determination of inflation.

The following table shows forecasts for potential output using both the aggregate and disaggregated methods, based on the inflation-adjusted series. The same series are shown for the previous five-year period for comparison. The forecasts for aggregate GDP and for productivity are derived from simple time-series models that relate current to past growth. The employment-population ratios are assumed to remain constant over the forecast period. This was done because these ratios, which are composed of the participation rate and the NAIRU, are not well-suited to simple time-series modelling. For instance, the NAIRU is assumed here, as is generally the case, to be a structural parameter that changes only due to unforeseen shocks. The participation rate may be somewhat more predictable, to the extent that it is related to shifts in the age distribution of the population, for example. However, less predictable shifts in preferences may also play a role. It is somewhat dangerous to simply extend a past trend in a variable of this type, since there are obvious limits to the extent that either an upward or downward trend can continue. Although it may be possible to use other types of information to refine the forecasts of both the participation rate and the NAIRU (for instance, a model that incorporates hysteresis effects), such efforts are beyond the scope of this paper. 
Growth in Potential Output and Components

(average annual rate of change)

\begin{tabular}{|c|c|c|c|c|c|}
\hline & $1990-1995$ & $1995-1997$ & & $1990-1995$ & $1995-1997$ \\
\hline Western Germany & & & Canada & & \\
\hline Aggregate & 1.6 & 1.6 & Aggregate & 2.1 & 2.5 \\
\hline Disaggregated & 1.0 & 2.4 & Disaggregated & 2.2 & 2.6 \\
\hline Productivity & 1.9 & 1.9 & Productivity & 1.2 & 1.2 \\
\hline Emp./Pop. & -1.2 & .0 & Emp./Pop. & -.3 & .0 \\
\hline Population & .3 & .5 & Population & 1.3 & 1.4 \\
\hline France & & & Japan & & \\
\hline Aggregate & 1.3 & 1.5 & Aggregate & .8 & 1.5 \\
\hline Disaggregated & 1.2 & 2.1 & Disaggregated & .7 & .5 \\
\hline Productivity & 1.4 & 1.3 & Productivity & .4 & .7 \\
\hline Emp./Pop. & -.5 & .0 & Emp./Pop. & .2 & .0 \\
\hline Population & .3 & .3 & Population & .1 & -.2 \\
\hline Italy & & & United States & & \\
\hline Aggregate & 1.3 & 2.0 & Aggregate & 2.4 & 2.4 \\
\hline Disaggregated & 1.4 & 2.8 & Disaggregated & 2.4 & 1.8 \\
\hline Productivity & 2.6 & 2.9 & Productivity & .9 & .8 \\
\hline Emp./Pop. & -1.1 & .0 & Emp./Pop. & .5 & .0 \\
\hline Population & -.1 & -.1 & Population & 1.0 & 1.0 \\
\hline \multicolumn{6}{|l|}{ United Kingdom } \\
\hline Aggregate & 2.3 & 2.2 & & & \\
\hline Disaggregated & 2.4 & 2.2 & & & \\
\hline Productivity & 2.8 & 2.0 & & & \\
\hline Emp./Pop. & -.6 & .0 & & & \\
\hline Population & .2 & .2 & & & \\
\hline
\end{tabular}


For the continental European countries (western Germany, France, and Italy), the disaggregated method produces a higher estimate of potential growth than the aggregate. This is primarily due to the fact that part of the recent low rate of potential output growth (which is essentially projected to continue by the time-series model) appears to be attributable to a sharp drop in the employment-population ratio, and this drop is not projected to continue. For the United Kingdom and Canada there is little difference between the two methods. For both Japan and the United States, the disaggregated method produces a lower estimate of potential growth than the aggregate method. The main reason is the converse of the explanation for the differences for the European countries. Employment-population ratios have risen in both of these countries in recent years; unless this trend continues or productivity growth accelerates, potential output growth is likely to slow. Another factor in the Japanese forecast is that the rate of working-age population growth is projected to turn from slightly positive to slightly negative, further depressing potential growth.

\section{Conclusion}

This paper has applied an augmented Hodrick-Prescott filter, developed by Laxton and Tetlow for estimating inflation-adjusted potential output, to both aggregate GDP and a disaggregation into labor productivity and employment components. The technique is generally successful in that reasonable estimates of sensitivity of inflation to output gaps are calculated, although they are not always significant, due most likely to multicollinearity and the limited size of the data set. The resulting estimates of inflation-adjusted output gaps appear to at least move the estimates of potential output in the right direction for the most part. Forecasts of potential output growth were derived using the inflation-adjusted series. 
The resulting differences between the aggregate and disaggregated versions suggest that taking account of the major components of growth is important in estimating trends in potential output.

Probably the most important difficulty with the application of this technique, as with applications of the simple HP filter, is the indeterminacy of the "best" weights in the optimization problem. The results presented in this paper use the traditional weight of 1600 for the trend, or smoothness, parameter, and a weight of 400 for the inflation parameter. Either or both of these could be adjusted. In particular, for the disaggregated method, it could be argued that underlying productivity growth should be treated as being much smoother than a weight of 1600 would imply. Because the employment-population ratio is generally more cyclical relative to trend than output, it could also be argued that a weight larger than 1600 should be used for that series.

Similarly, the more closely one wants to tie potential output to inflation, the greater the weight on inflation should be. The latter point is particularly important because potential output is after all a constructed series that by definition is supposed to be the amount that the economy can produce without causing inflation to accelerate. The only reason we give any weight to the other components (the actual level and a smooth trend) must be that we think that the inflation series has enough noise in it that we should not take it literally period-byperiod. Future research might profitably be directed at determining more precisely how we should balance these various objectives in constructing potential output. 


\section{Chart 1}

\section{Output Gaps and Inflation Acceleration}

Western Germany

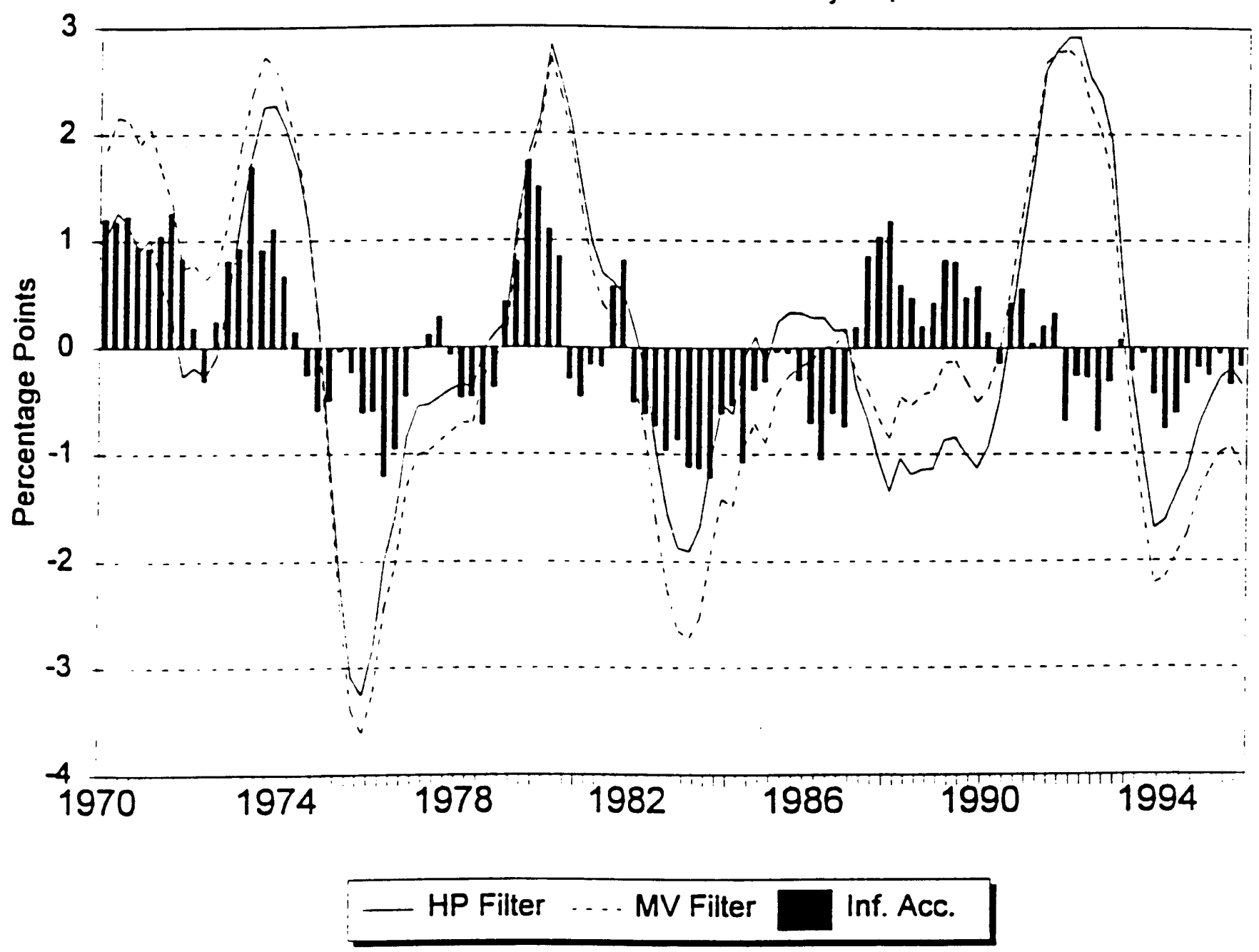




\section{Chart 2}

Output Gaps and Inflation Acceleration

France

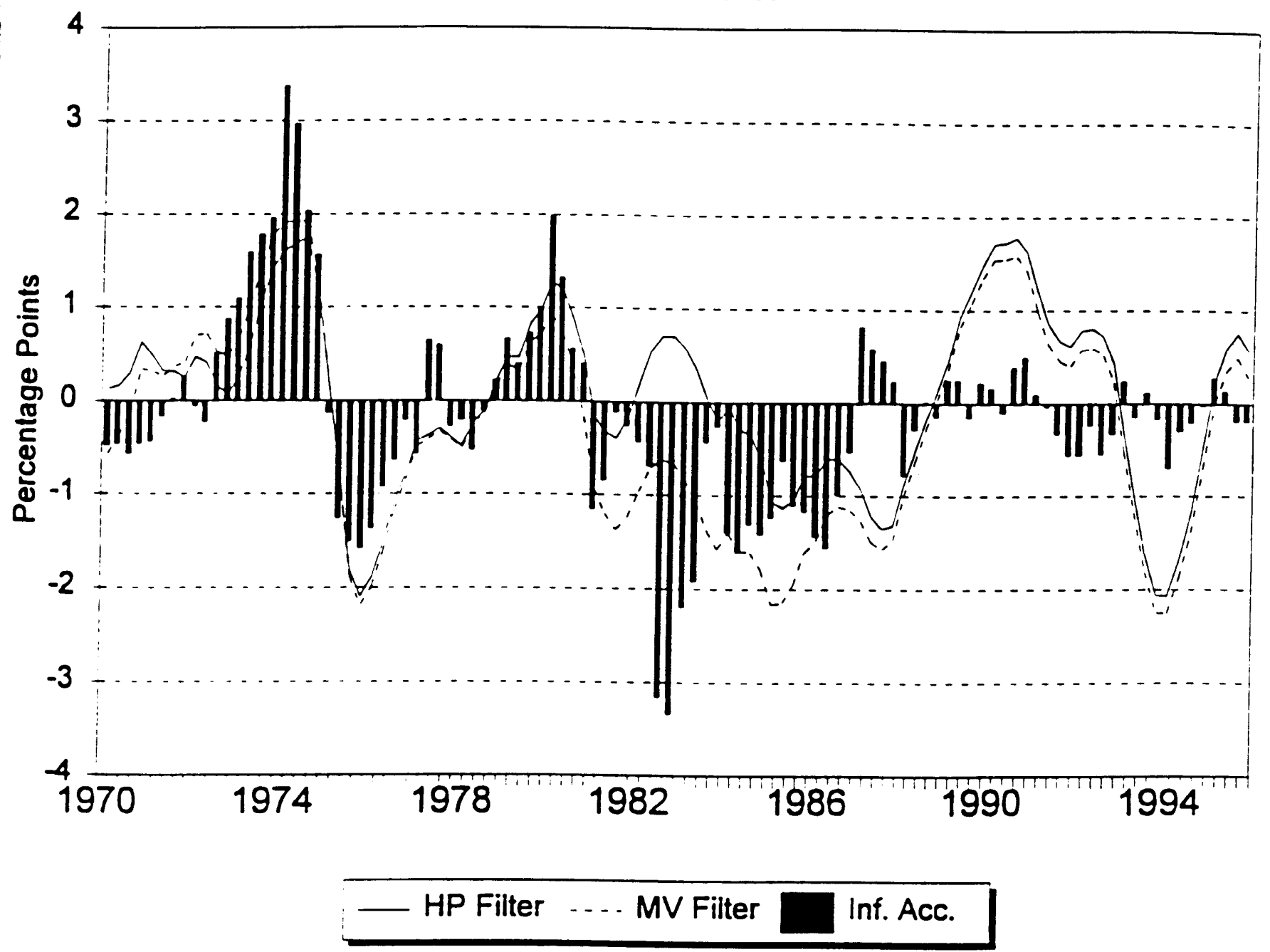




\section{Chart 3}

\section{Output Gaps and Inflation Acceleration}

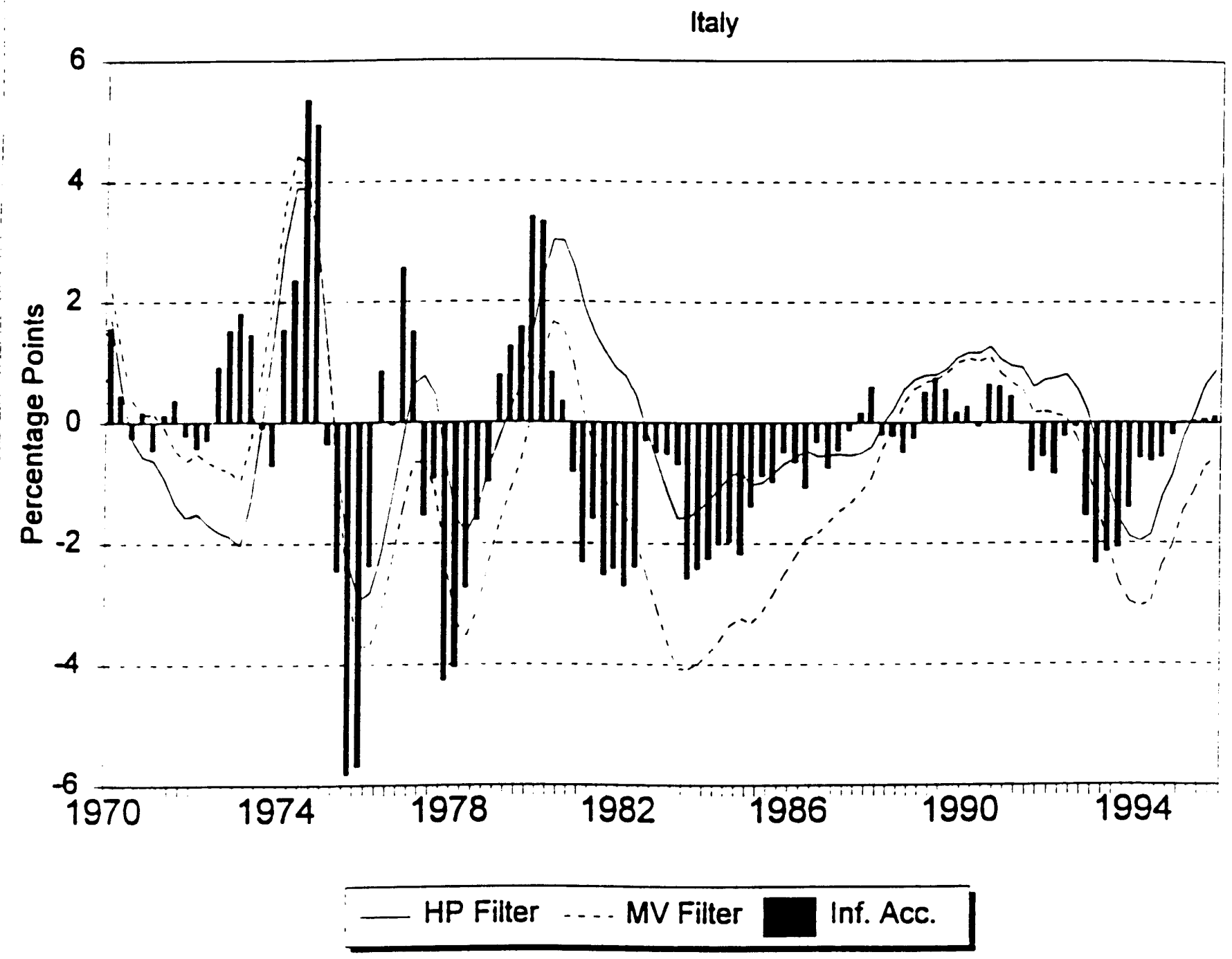




\section{Chart 4}

Output Gaps and Inflation Acceleration United Kingdom

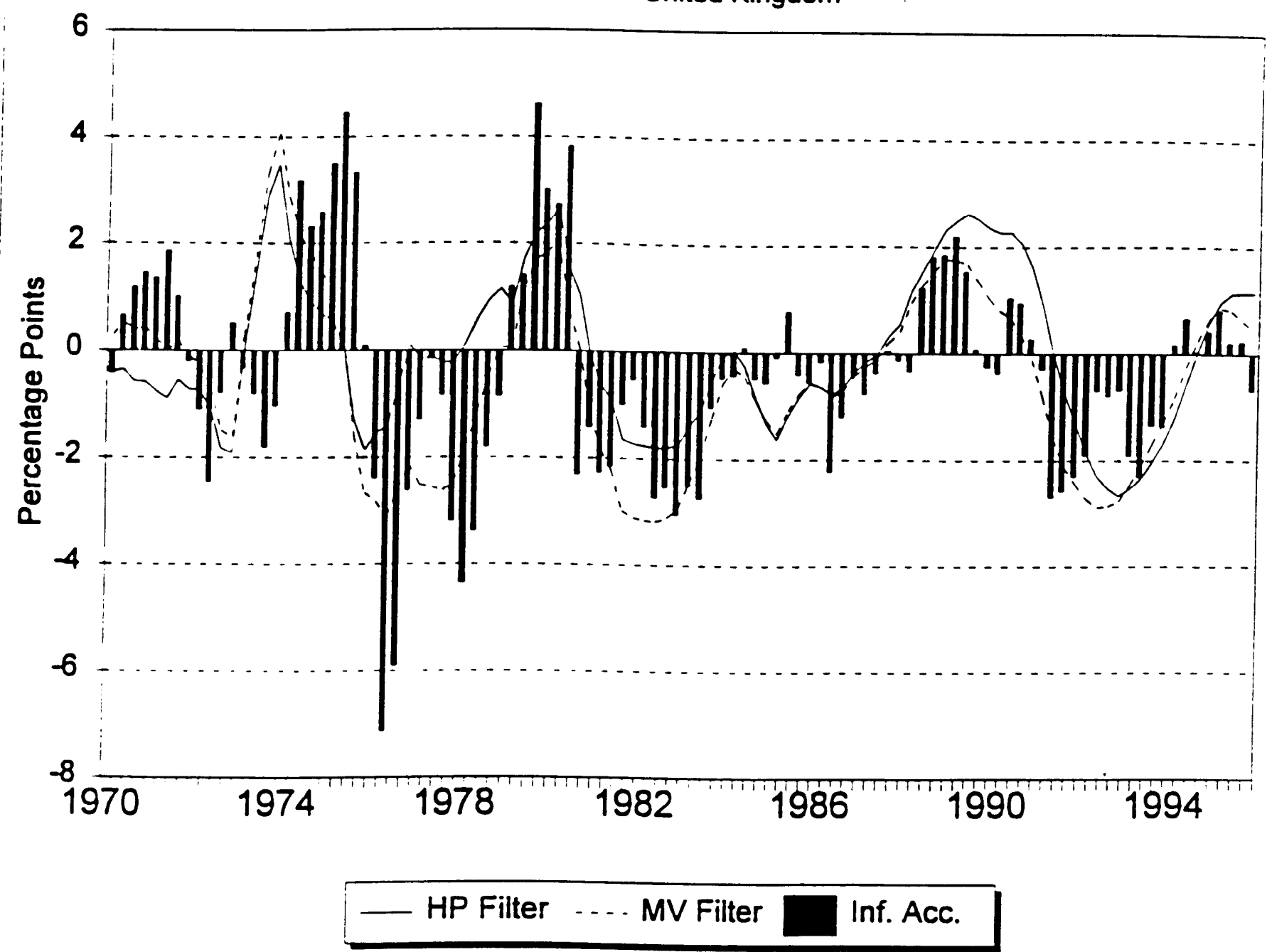




\section{Chart 5}

\section{Output Gaps and Inflation Acceleration}

\section{Canada}

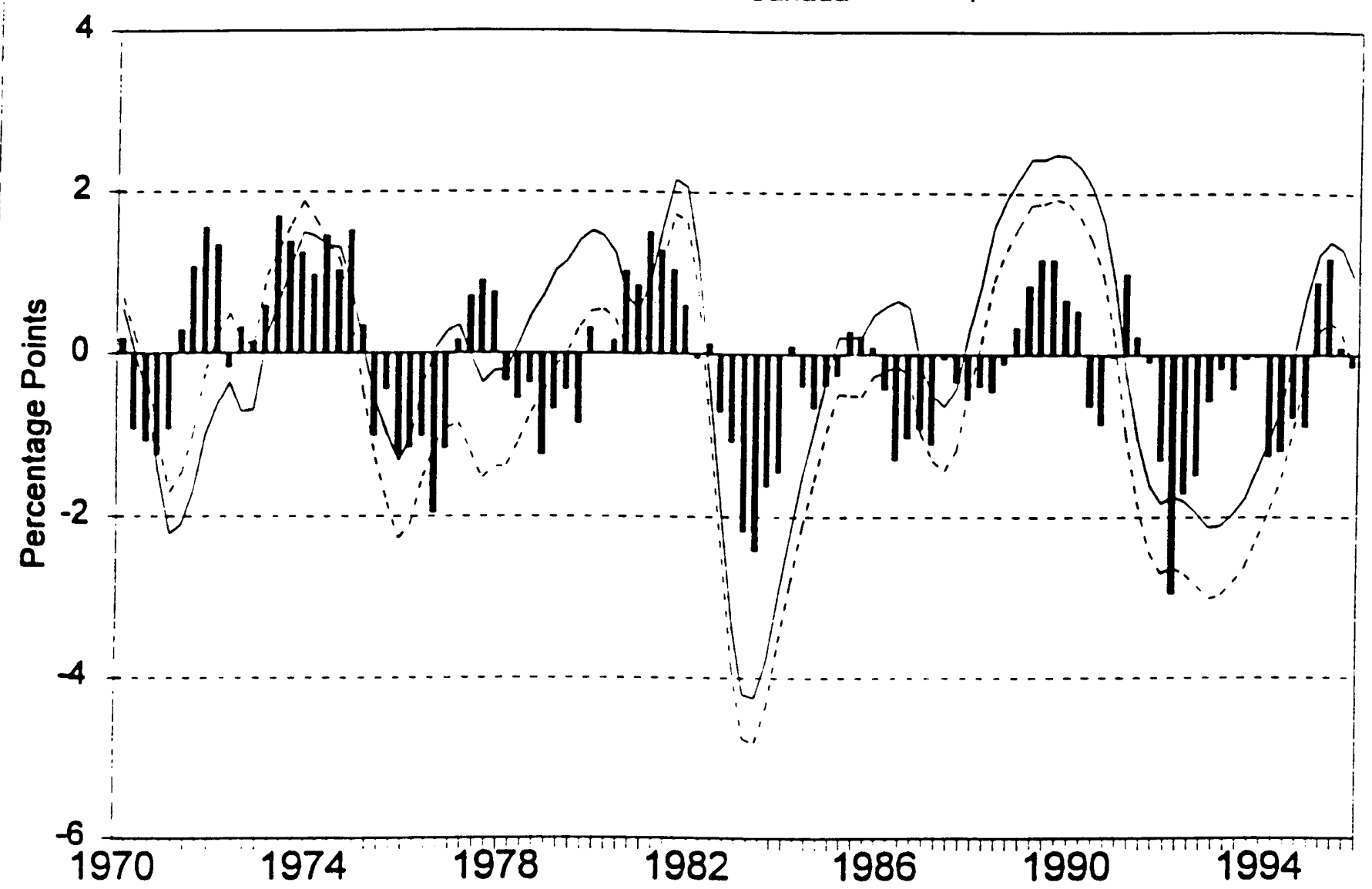




\section{Chart 6}

Output Gaps and Inflation Acceleration

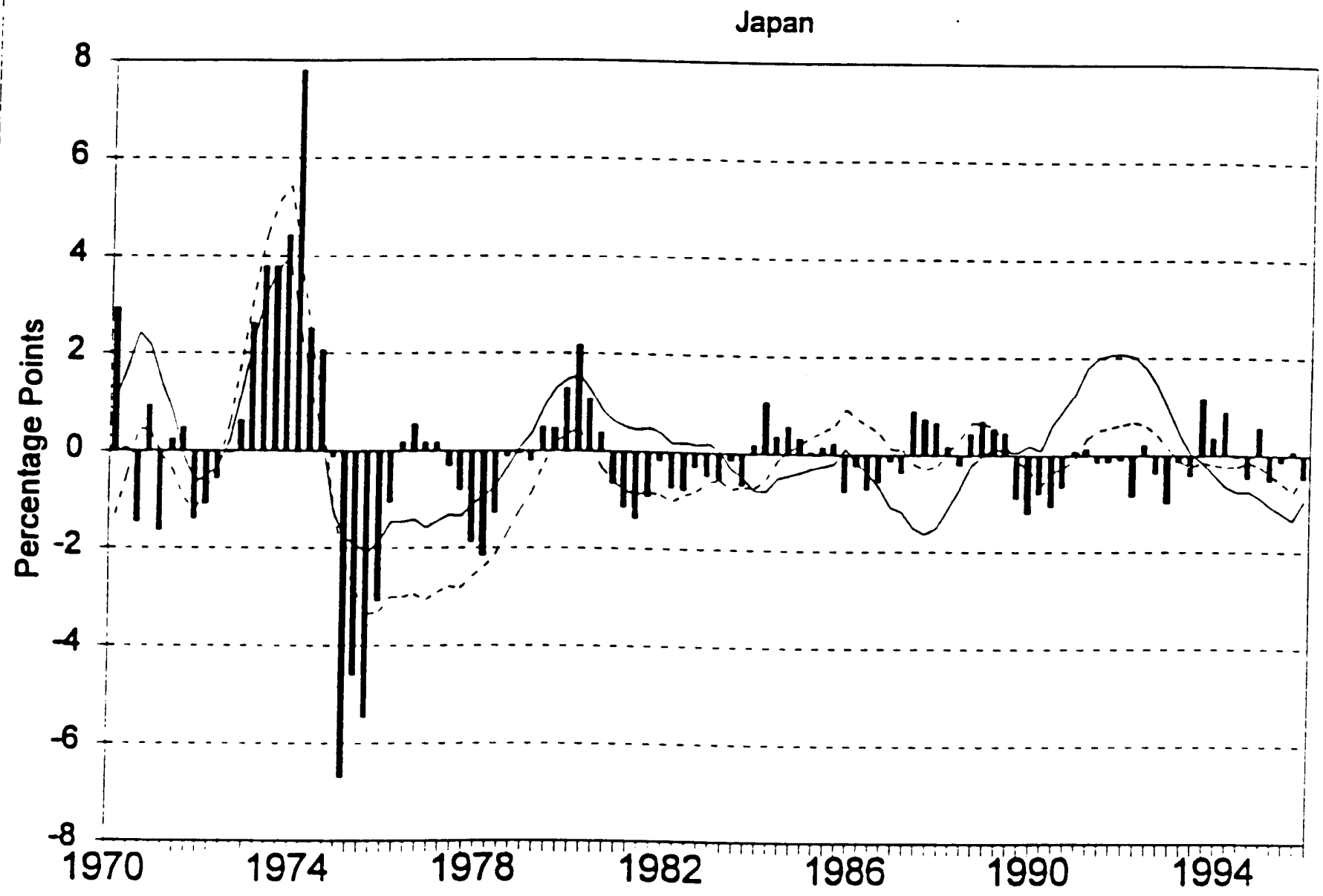




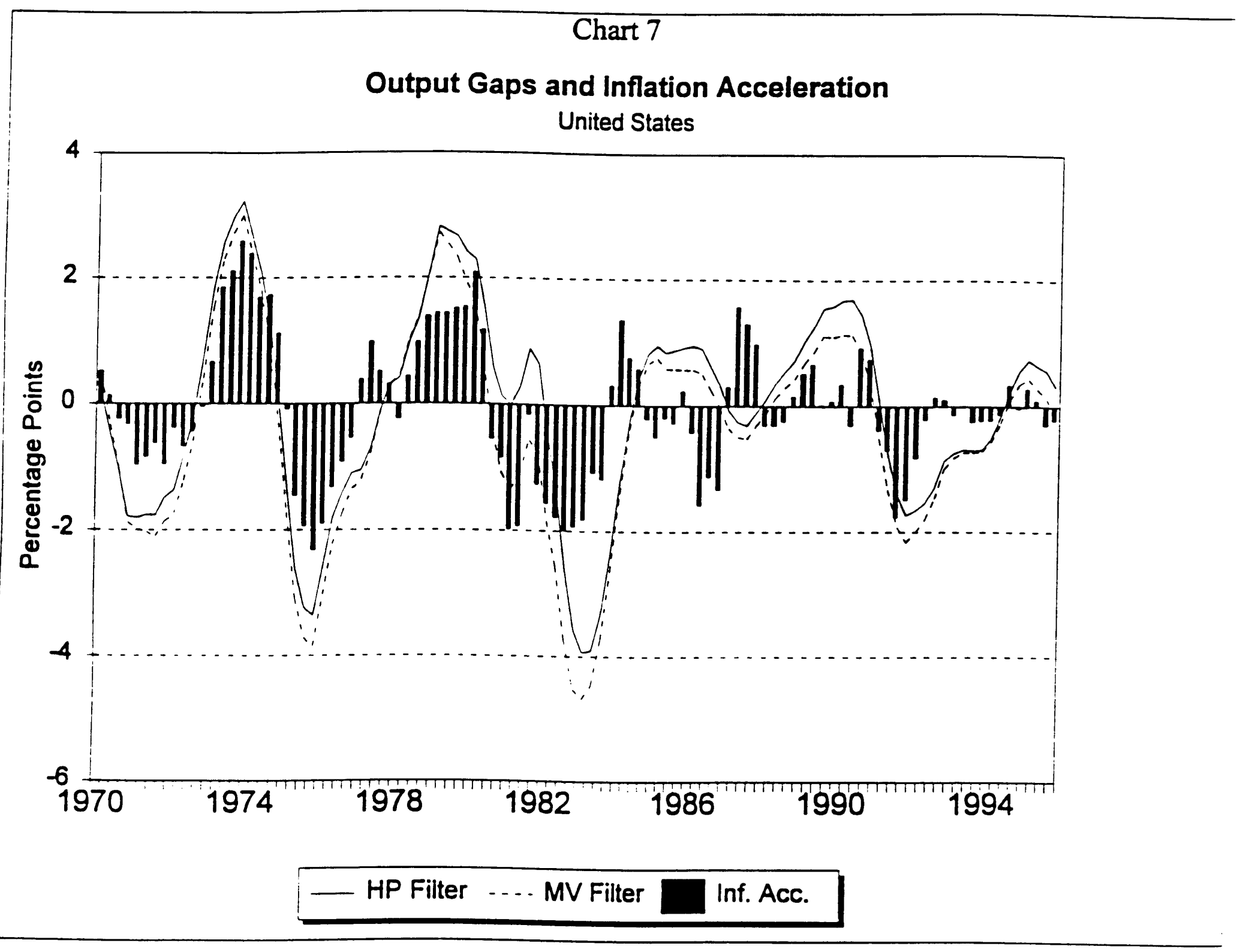




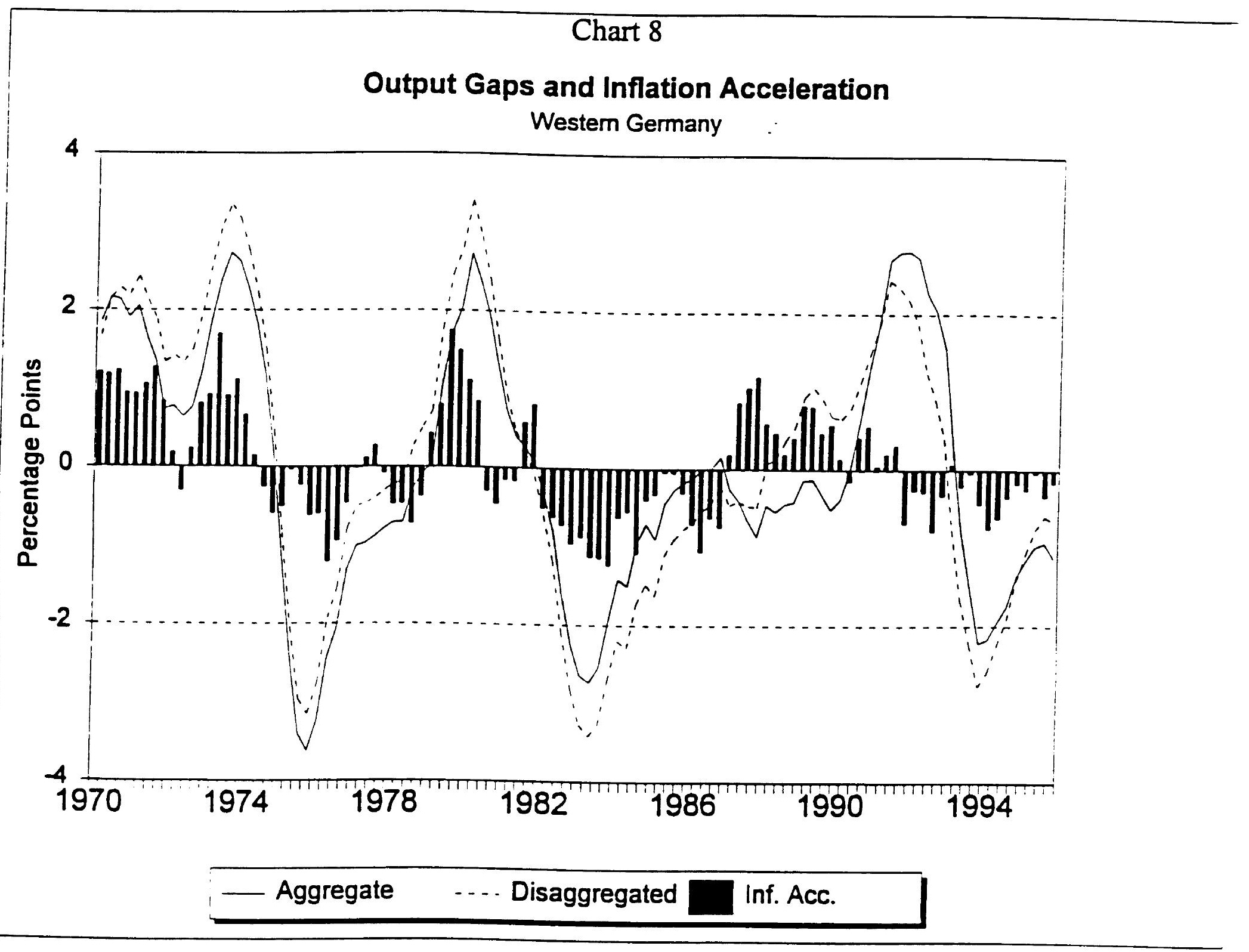




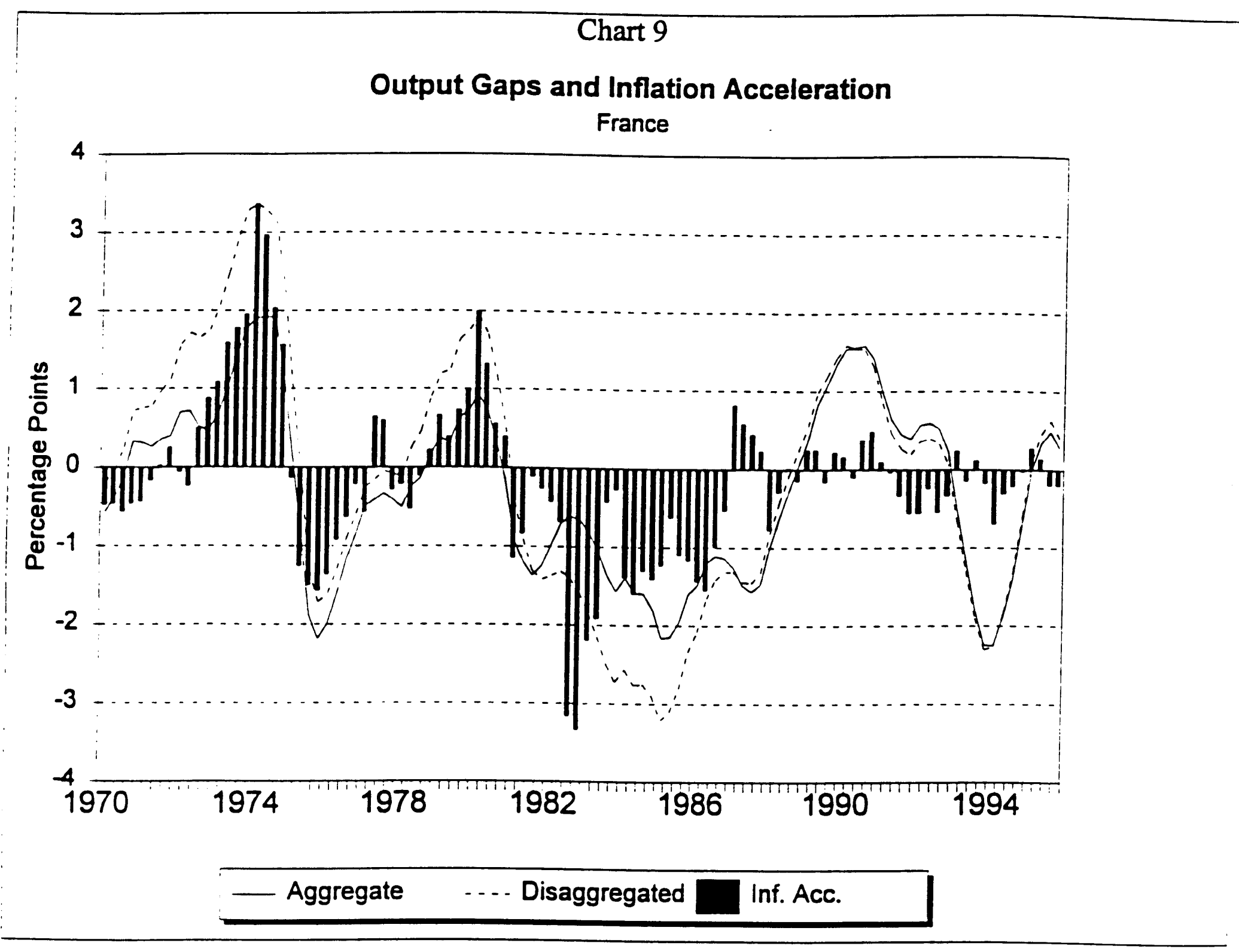




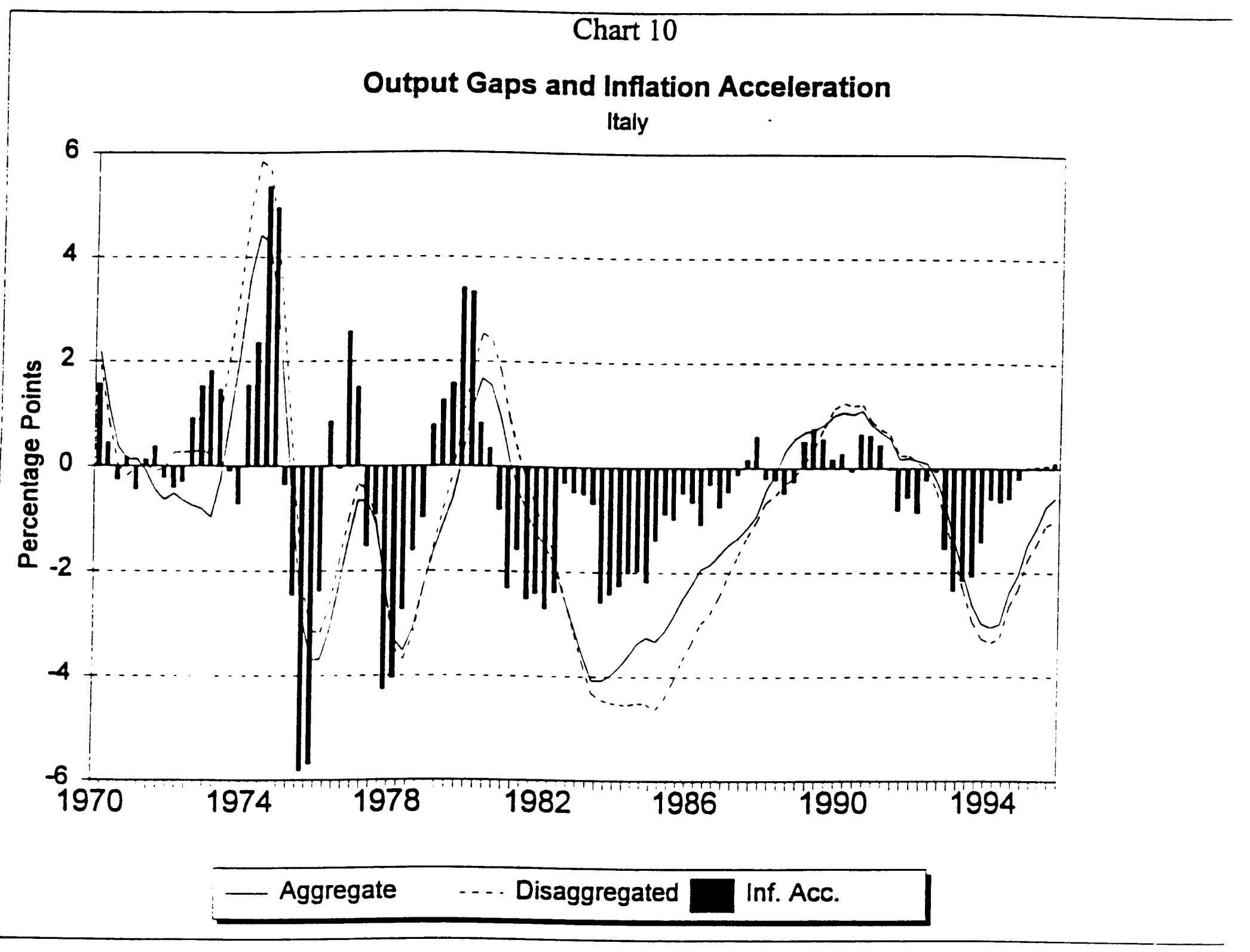




\section{Chart 11}

\section{Output Gaps and Inflation Acceleration}

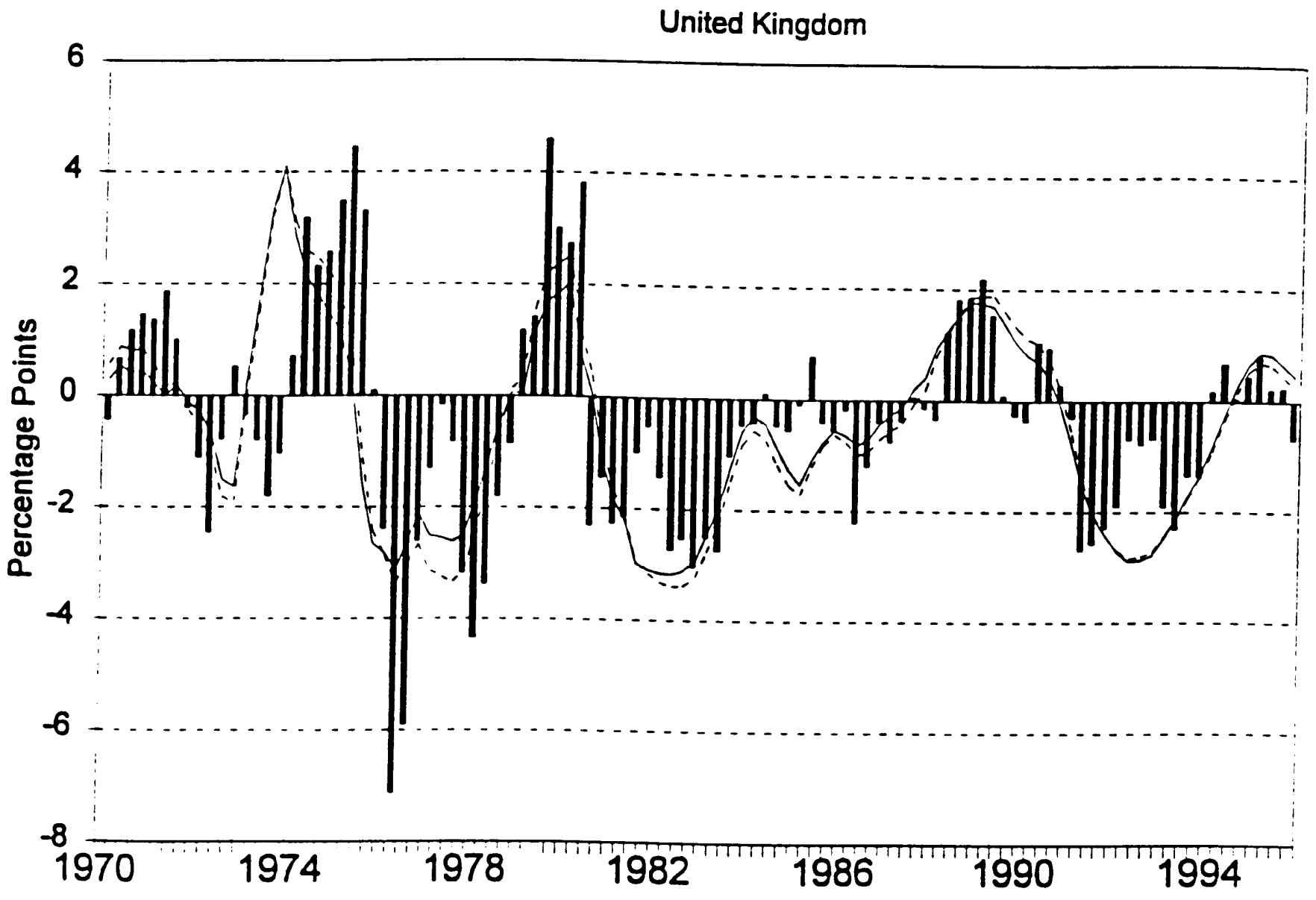

$$
\text { Aggregate -... Disaggregated }
$$

Inf. Acc. 


\section{Chart 12}

Output Gaps and Inflation Acceleration Canada

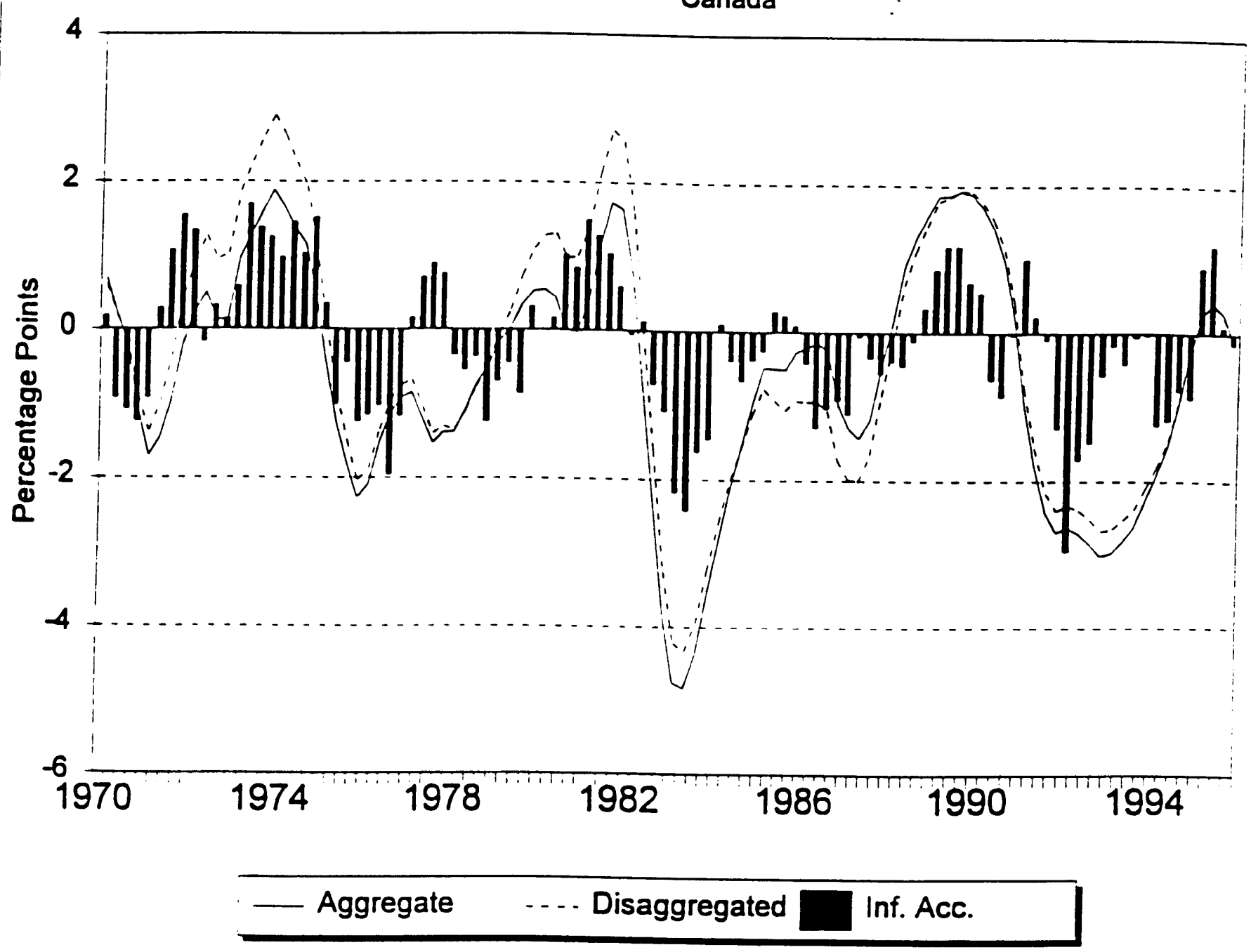




\section{Chart 13}

\section{Output Gaps and Inflation Acceleration}

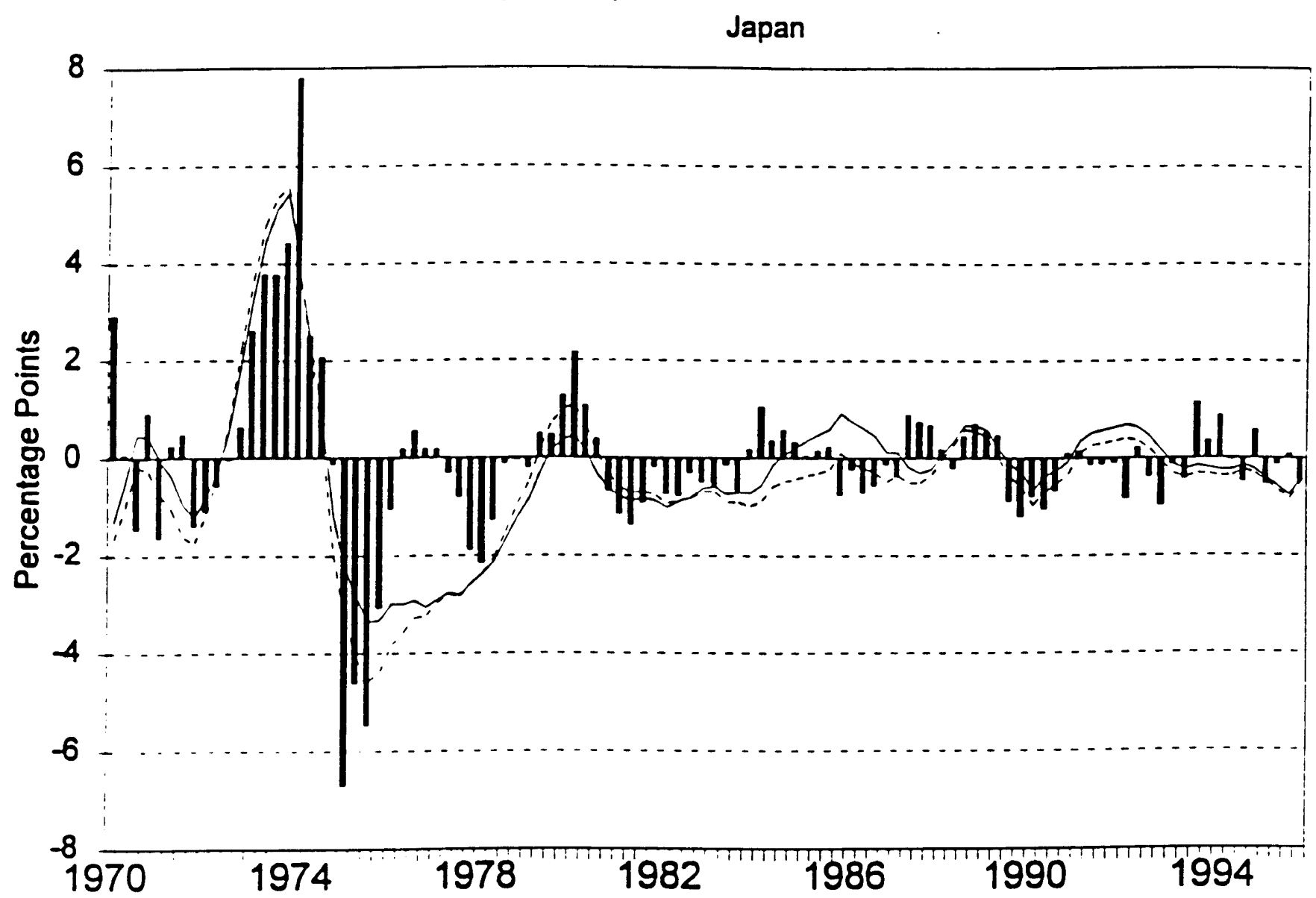




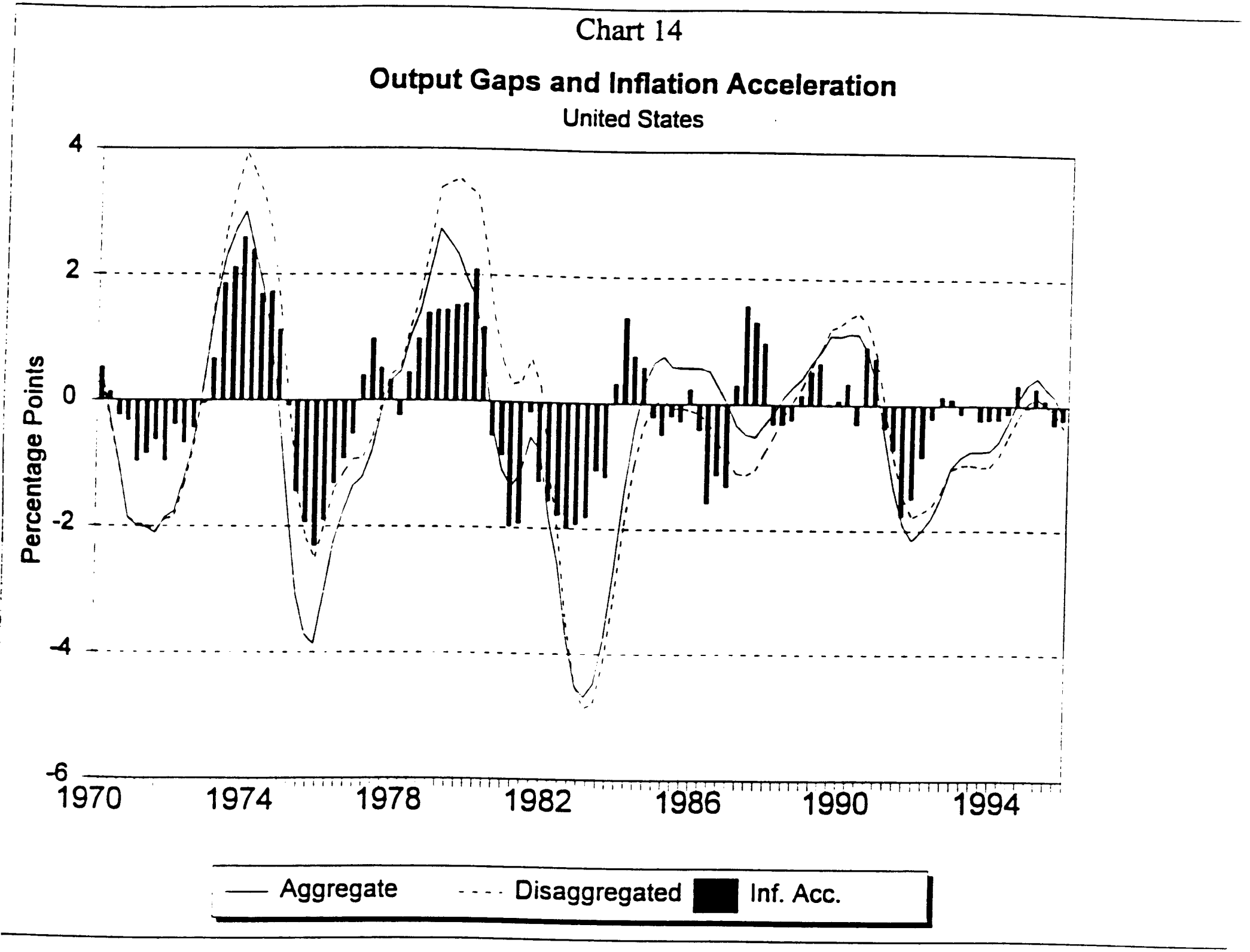




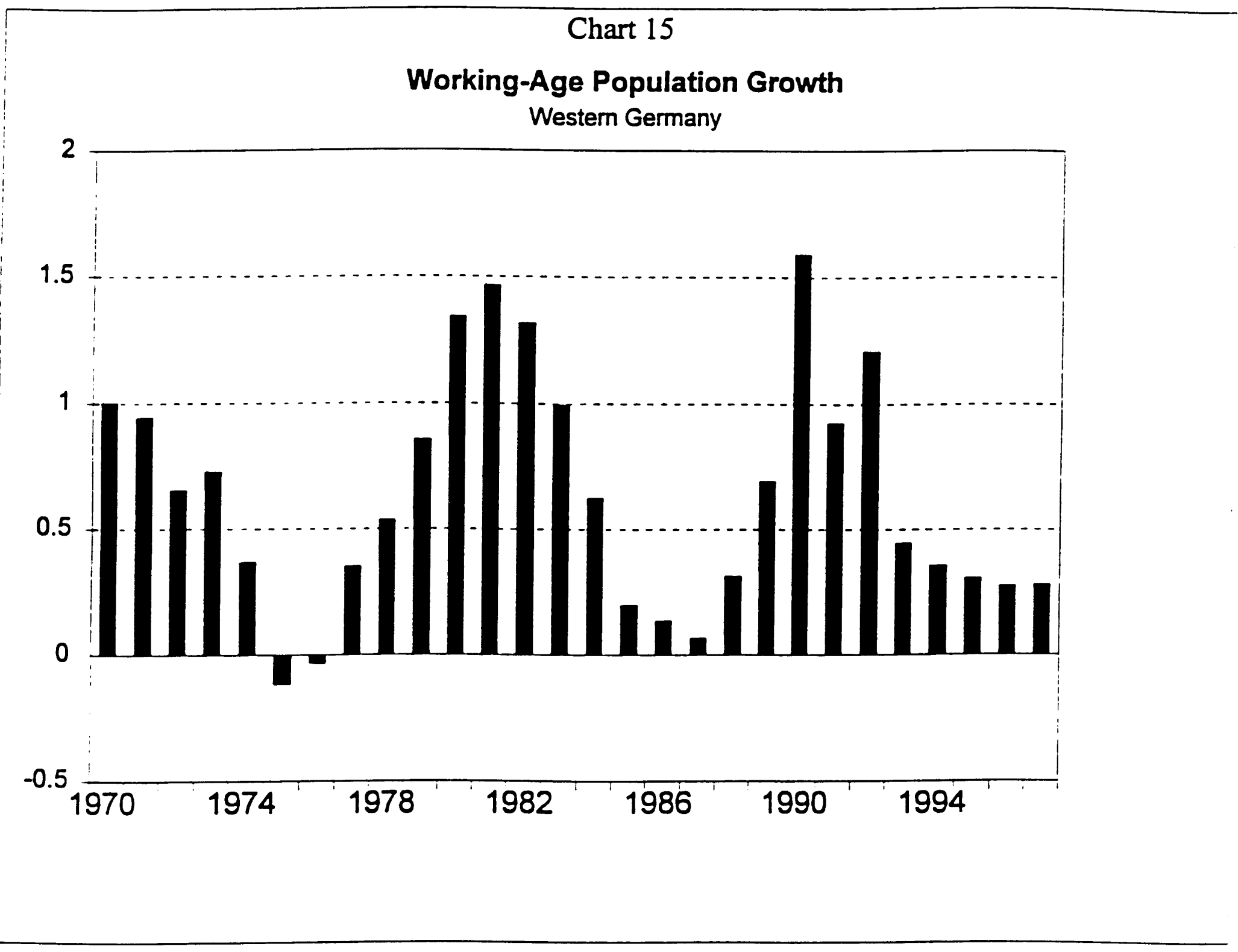




\section{Chart 16}

\section{Working-Age Population Growth}

France

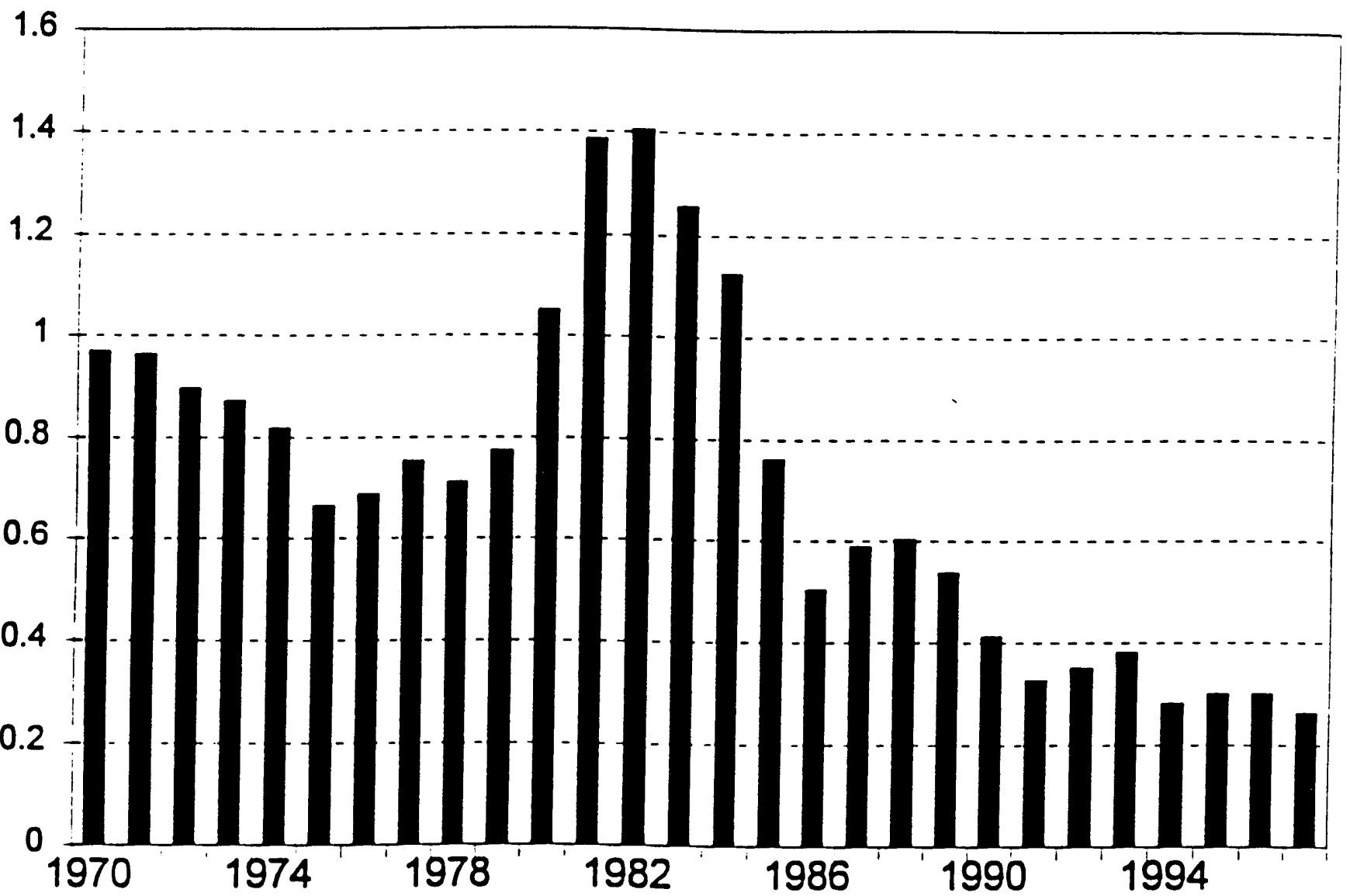




\section{Chart 17}

\section{Working-Age Population Growth} Italy

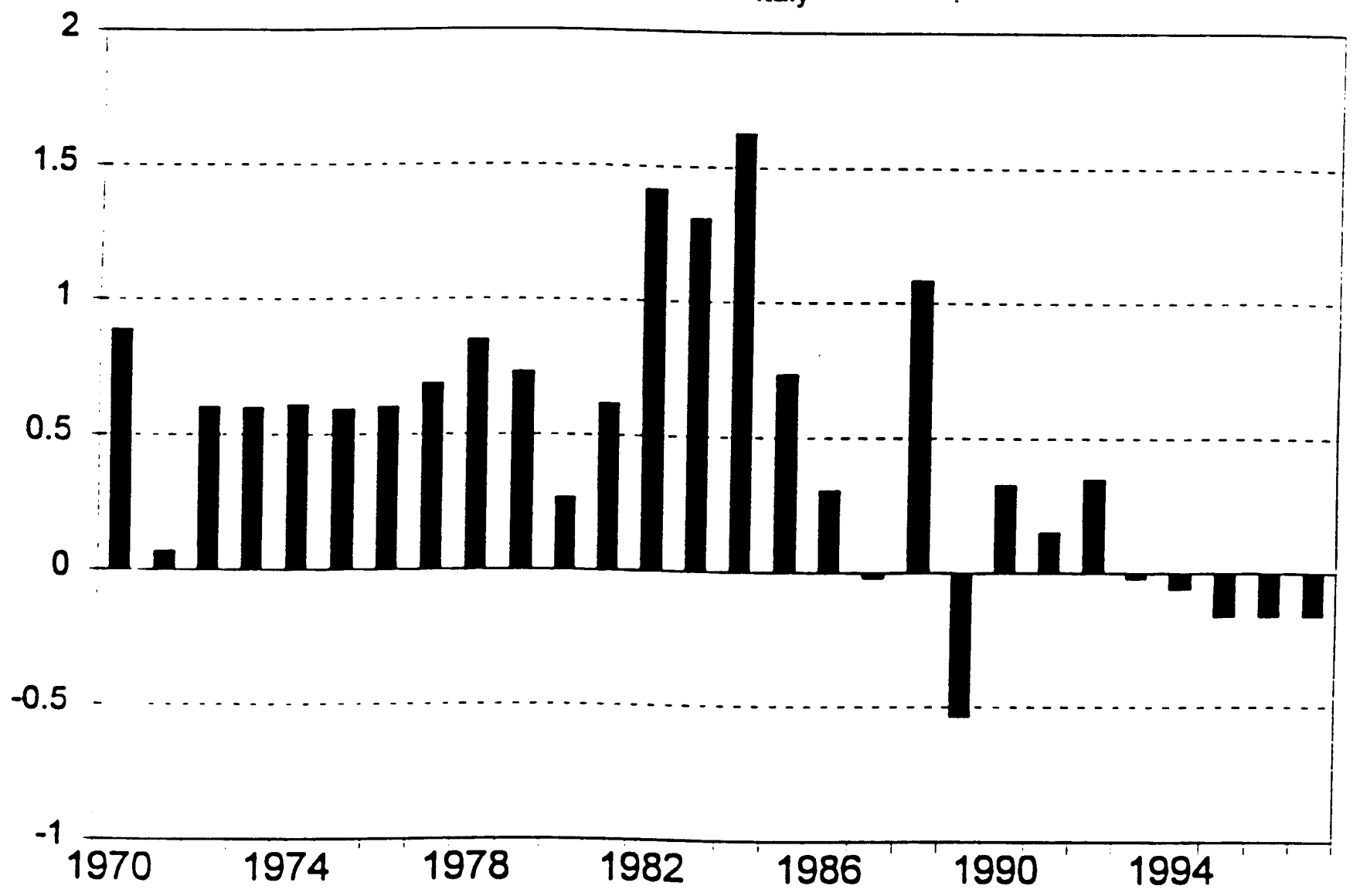


Chart 18

\section{Working-Age Population Growth}

United Kingdom

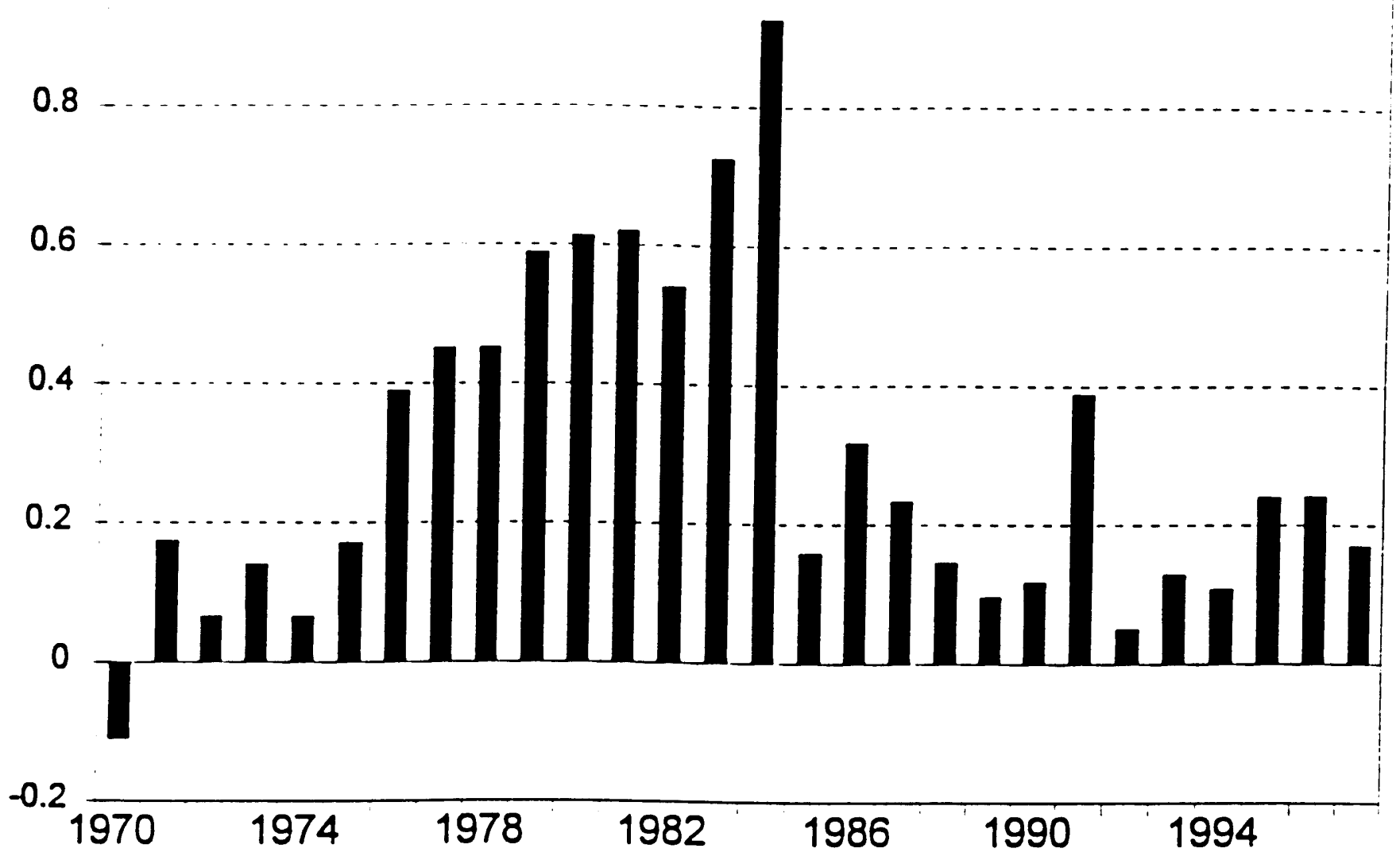


Chart 19

Working-Age Population Growth

Canada

3

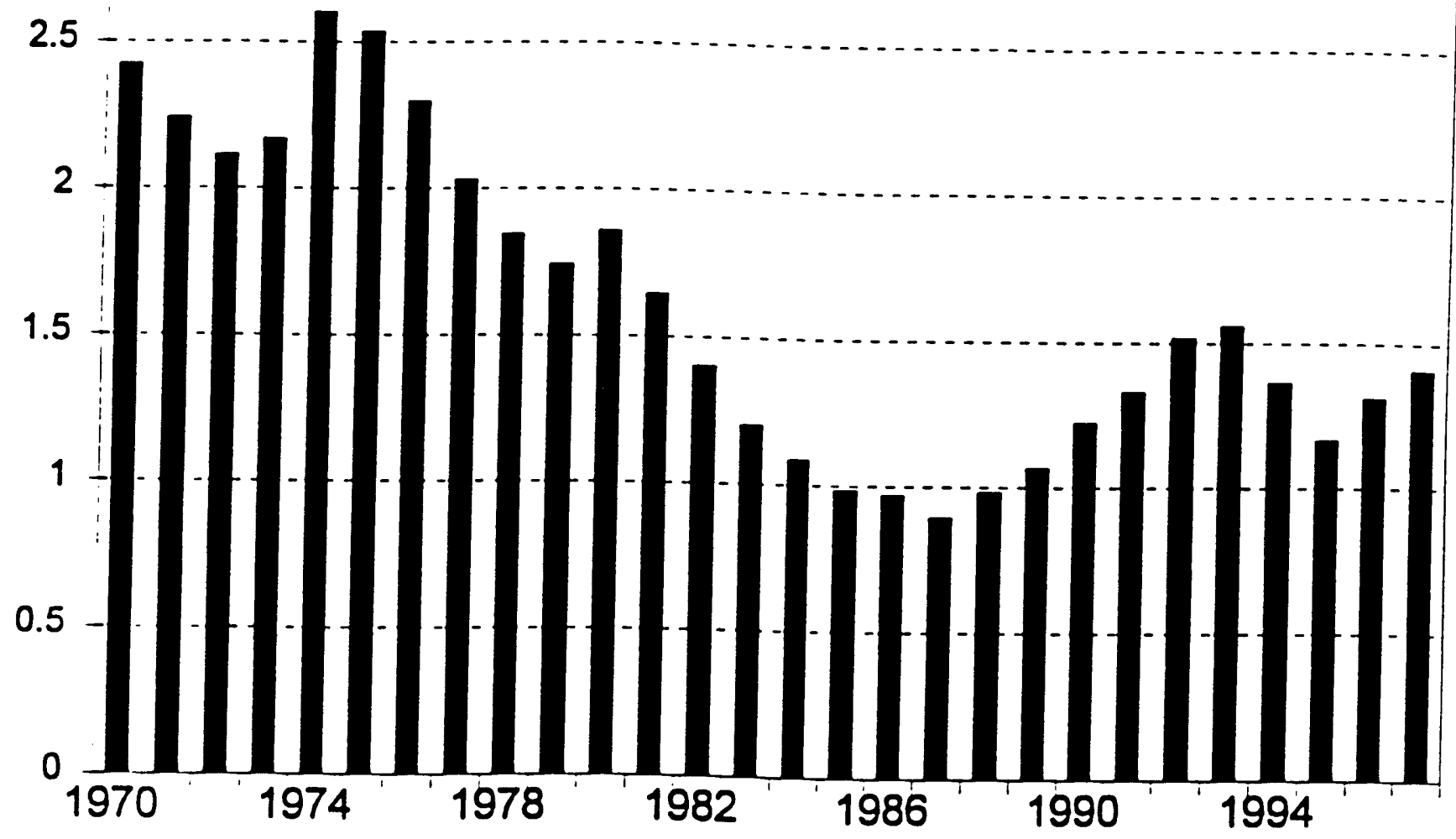


Chart 20

Working-Age Population Growth Japan

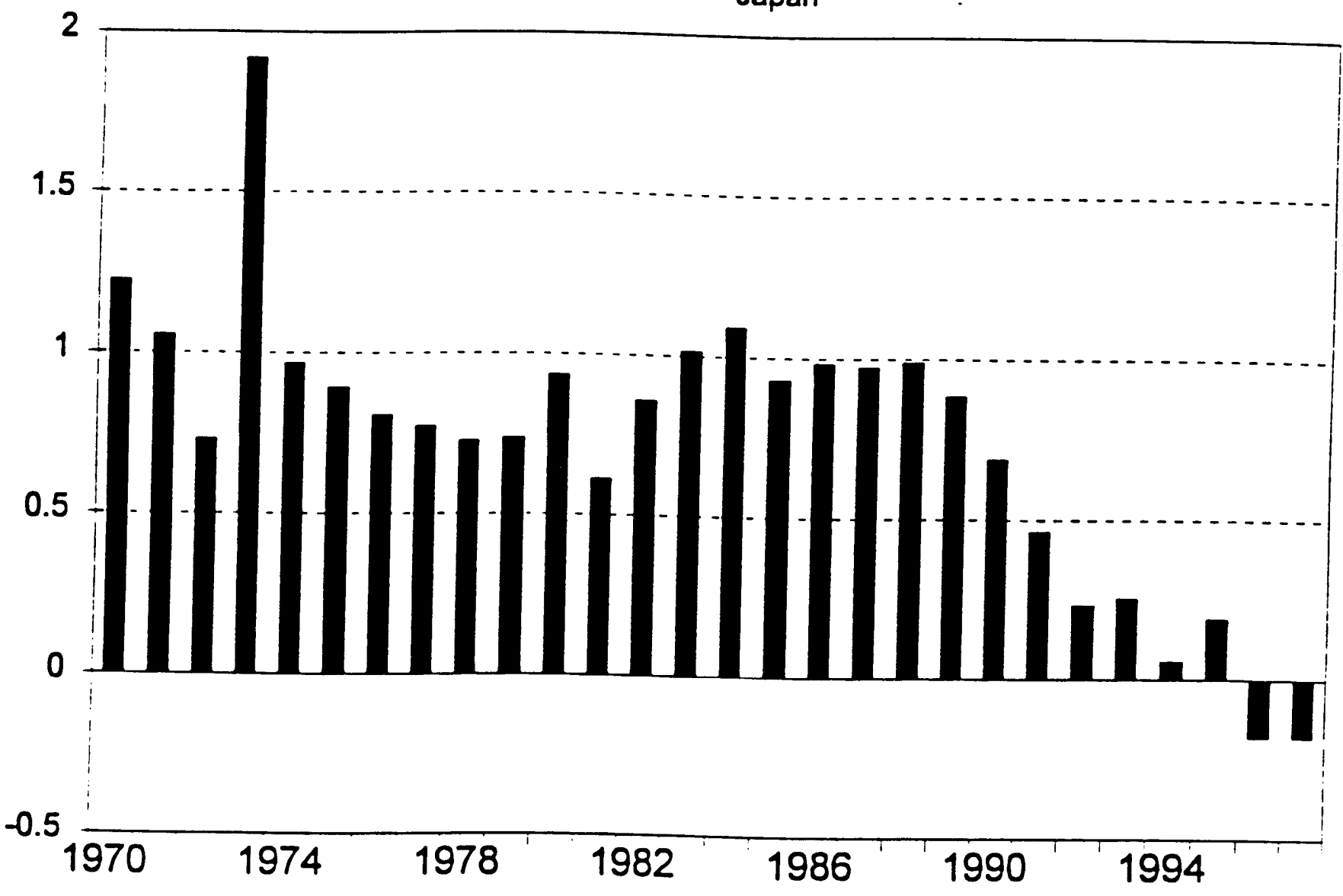




\section{Chart 21}

\section{Working-Age Population Growth}

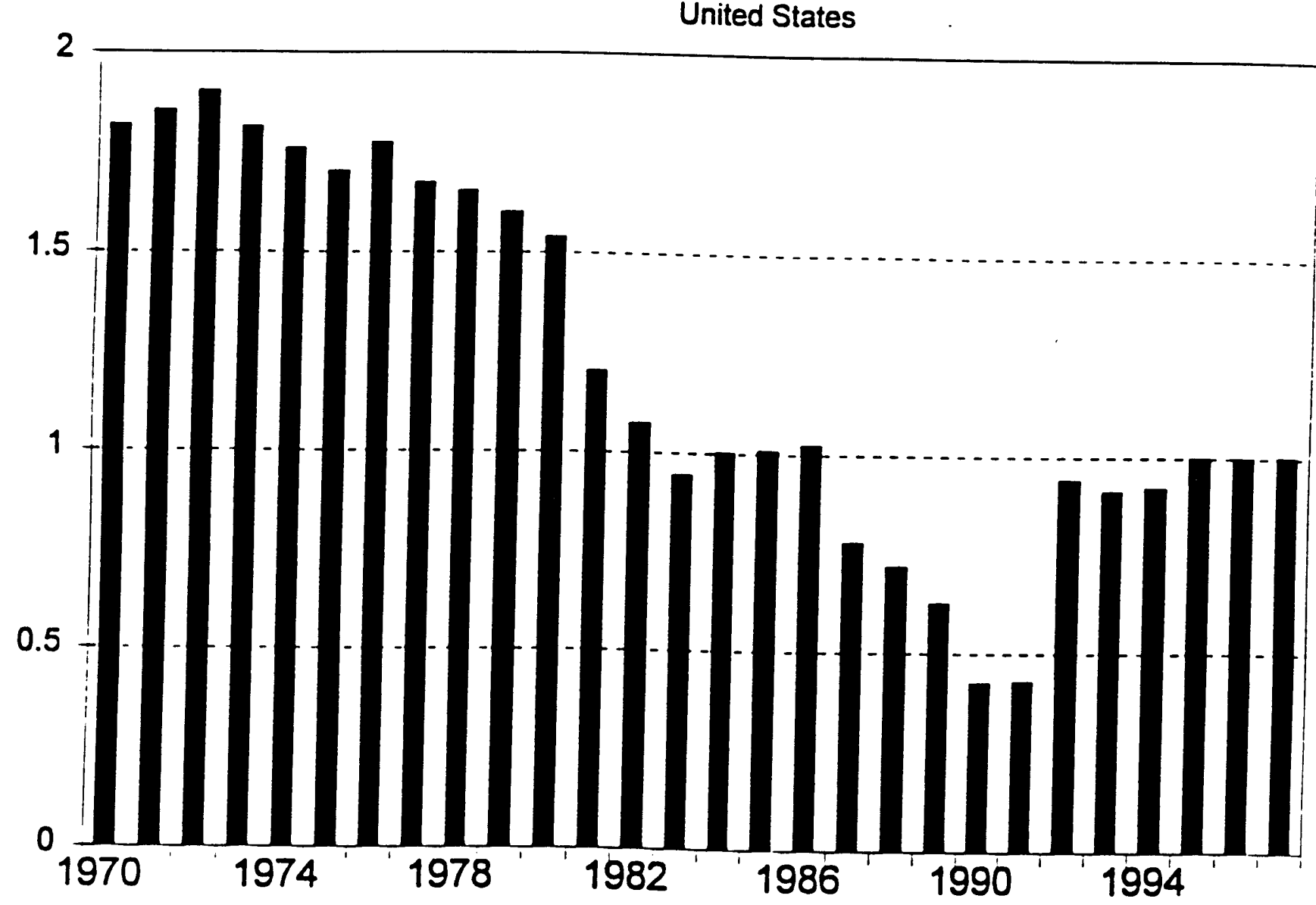


Appendix

Charts A1 through A7 compare the output gaps obtained using weights of 200,400 , and 800 on the inflation term. (As noted earlier, 400 was used for the main set of results.) The differences are fairly small for most time periods, but can be substantial, particularly for France and Italy in the mid-1980's. One way to view the choice of $\alpha$ is as depending primarily on how much more of the residual in the inflation equation one wishes to explain by altering the output gap. As shown in the top part of the following table, the percentage of the inflation acceleration term explained by the output gap increases substantially, although unevenly among countries, as $\alpha$ increases. However, as shown in the lower panel, the standard deviation of the output gap also increases a fair amount, particularly for Italy. (The variation among countries may suggest that the choice of $\alpha$ should also vary by country. ${ }^{7}$ ) The results shown in the table suggest that the improvement in the "fit" of the inflation equation is larger relative to the increase in the standard deviation of the gap as $\alpha$ increases from 0 to 400 than it is as $\alpha$ increases from 400 to 800 . This provides some justification for the choice of $\alpha$ used here, although certainly a more well-grounded criteria would be preferable.

7 The same is also true for the choice of $\lambda$, although in practice 1600 continues to be most commonly used. 


\begin{tabular}{||l|c|c|c|c|c||}
\hline \multicolumn{1}{|c|}{ Percent of Inflation Acceleration Explained and Standard Deviation of Output Gap For Different Values of $\alpha$} \\
\hline & $\alpha=0$ & $\alpha=200$ & $\alpha=400$ & $\alpha=800$ \\
\hline W. Germany & \multicolumn{2}{|c|}{ Percent of Inflation Acceleration Explained } \\
\hline France & 12 & 15 & \multicolumn{2}{c||}{18} & 21 \\
\hline Italy & 4 & 9 & 12 & 16 \\
\hline United Kingdom & 7 & 10 & 12 & 15 \\
\hline Canada & 8 & 13 & 16 & 18 \\
\hline Japan & 10 & 13 & 14 & 16 \\
\hline United States & 19 & 15 & 18 & 22 \\
\hline & 18 & 21 & 22 & 25 \\
\hline W. Germany & \multicolumn{1}{|c|}{ Standard Deviation of the Output Gap (percent) } \\
\hline France & 1.6 & 1.7 & 1.8 & 2.0 \\
\hline Italy & 1.1 & 1.1 & 1.2 & 1.4 \\
\hline United Kingdom & 1.6 & 1.8 & 2.0 & 2.4 \\
\hline Canada & 1.7 & 1.8 & 1.9 & 2.1 \\
\hline Japan & 1.7 & 1.7 & 1.7 & 1.8 \\
\hline United States & 1.4 & 1.5 & 1.7 & 1.9 \\
\hline
\end{tabular}




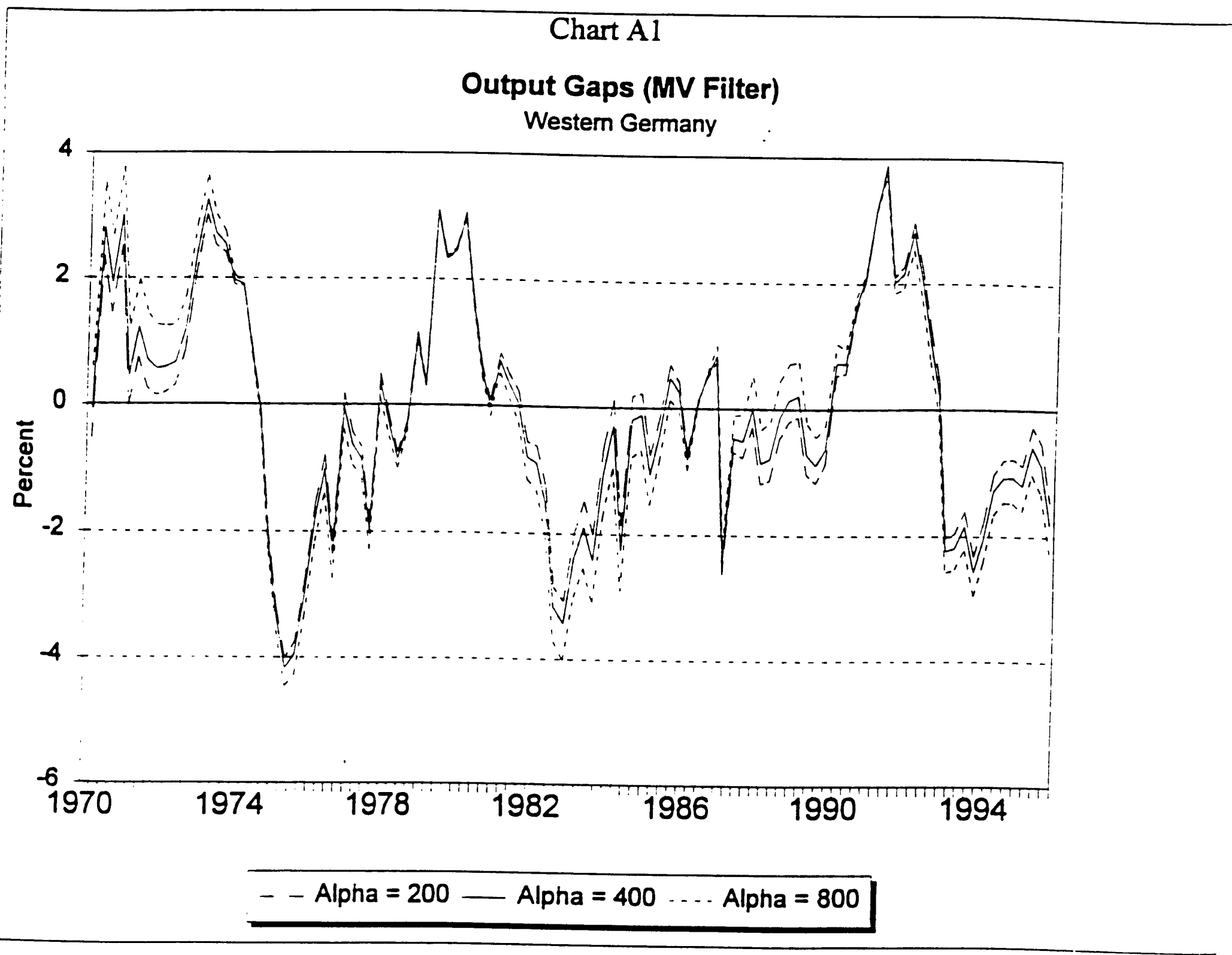




\section{Chart A2}

\section{Output Gaps (MV Filter)}

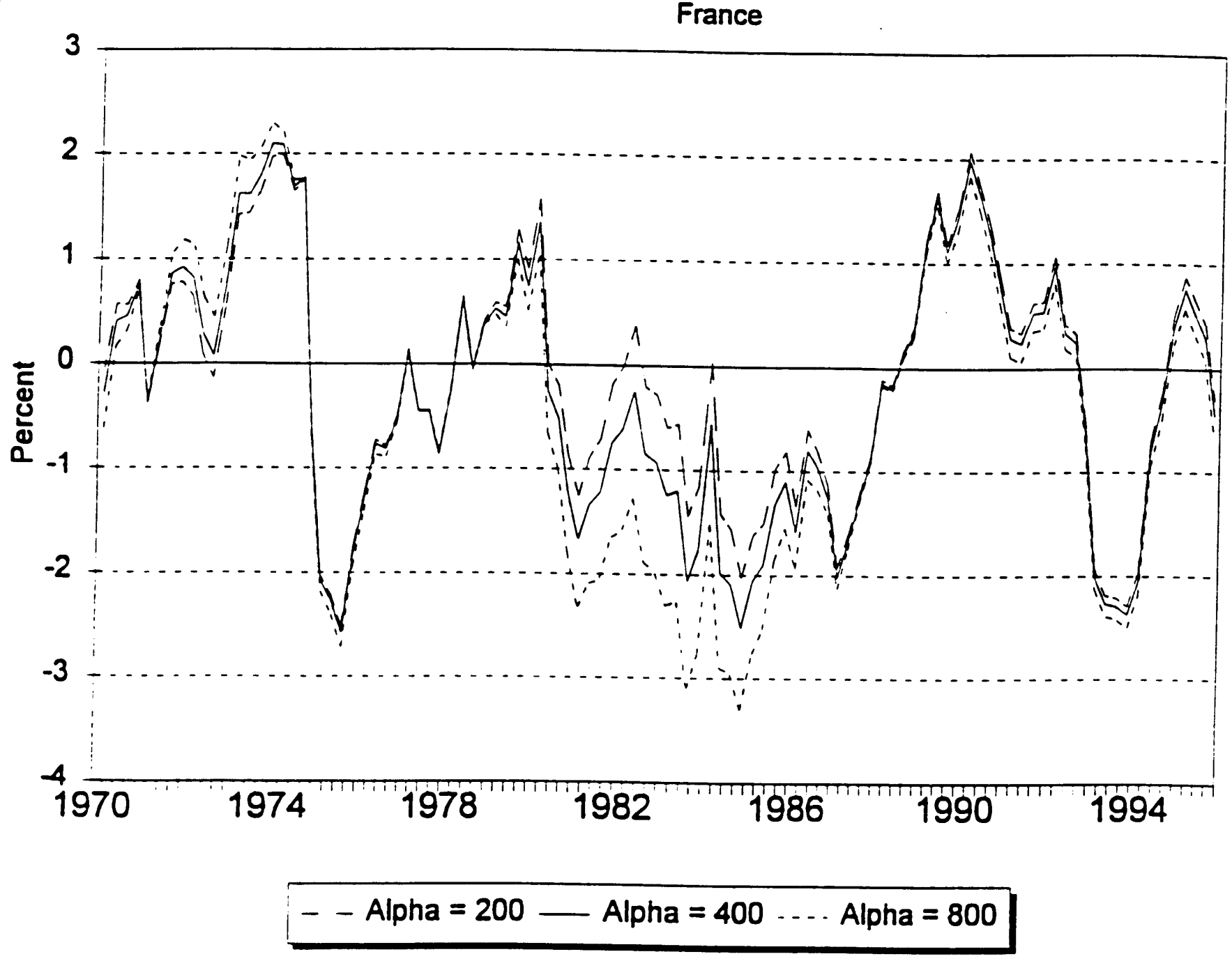


Chart A3

Output Gaps (MV Filter)

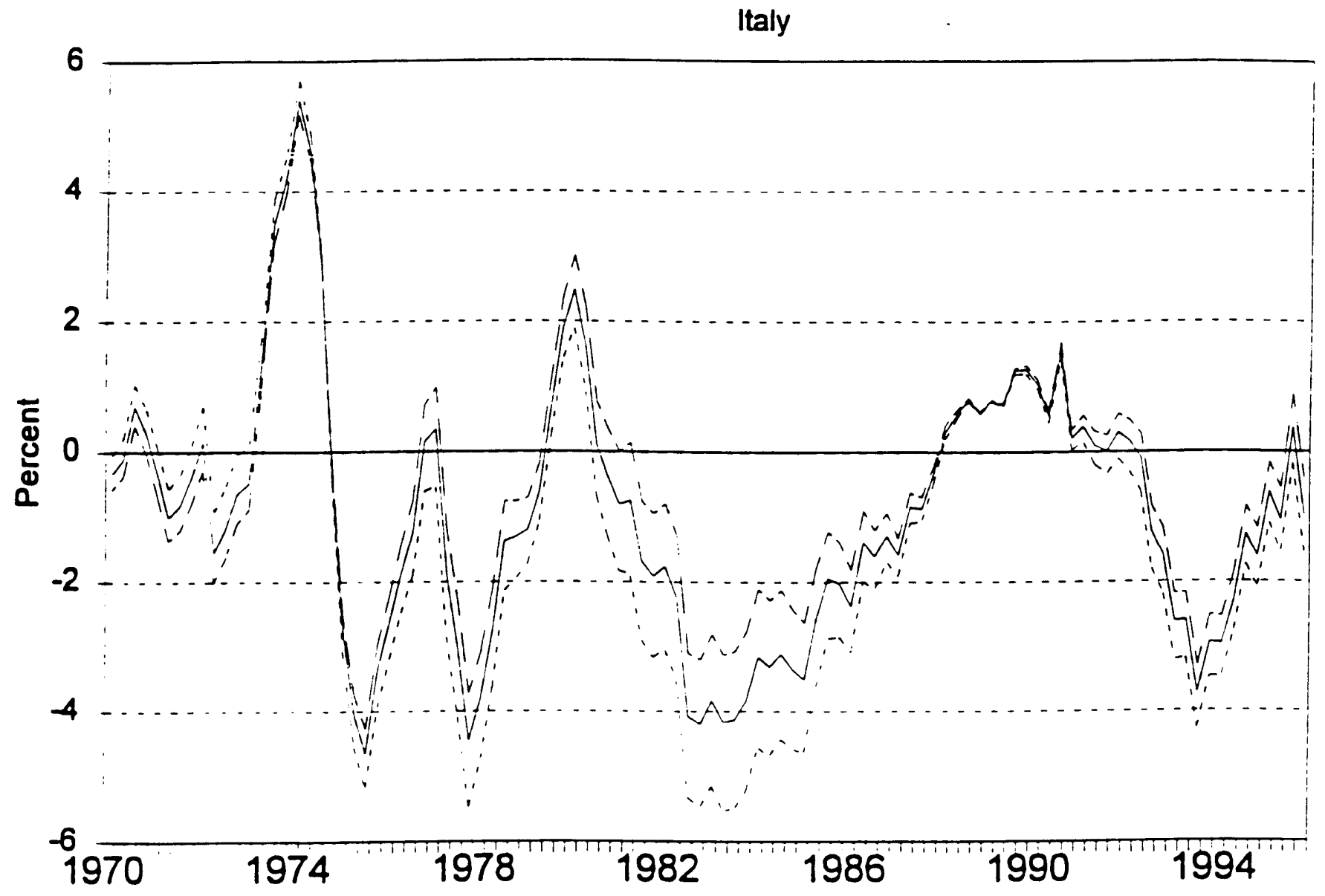

- Alpha $=200-$ Alpha $=400 \ldots$ Alpha $=800$ 


\section{Chart A4}

\section{Output Gaps (MV Filter)}

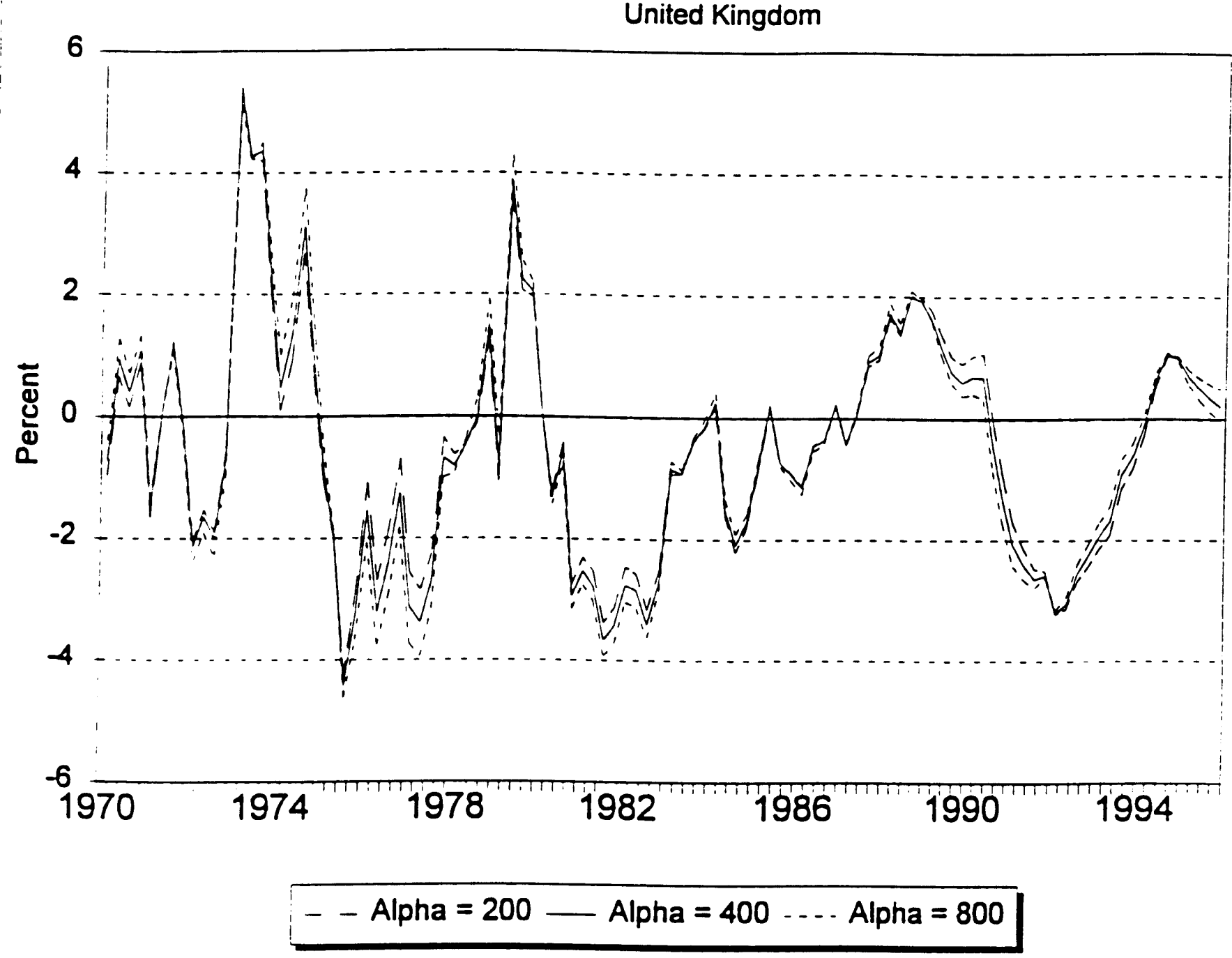




\section{Chart A5}

\section{Output Gaps (MV Filter)}

\section{Canada}

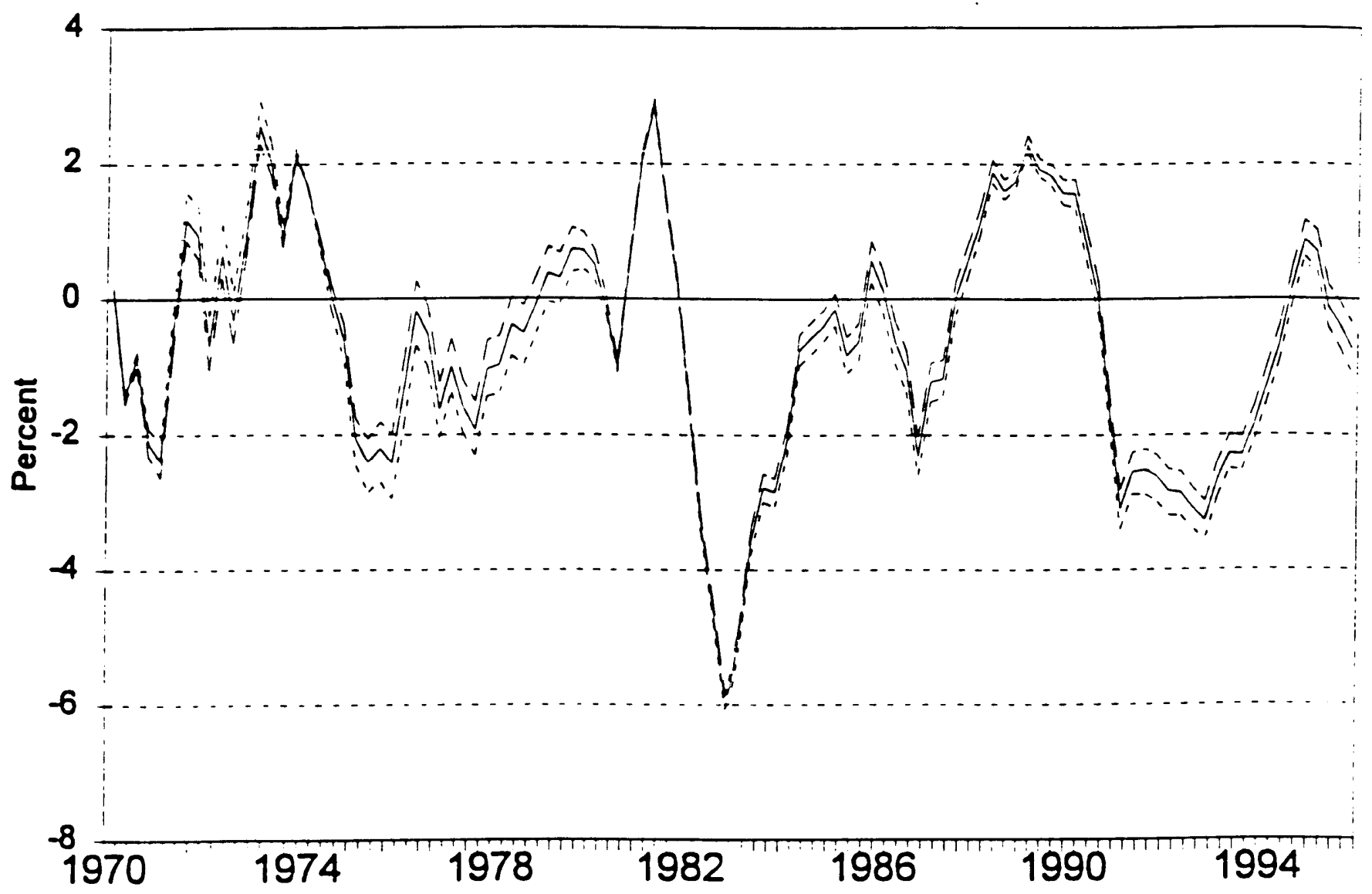

$$
\text { - Alpha }=200-\text { Alpha }=400 \ldots \text { Alpha }=800
$$


Chart A6

Output Gaps (MV Filter)

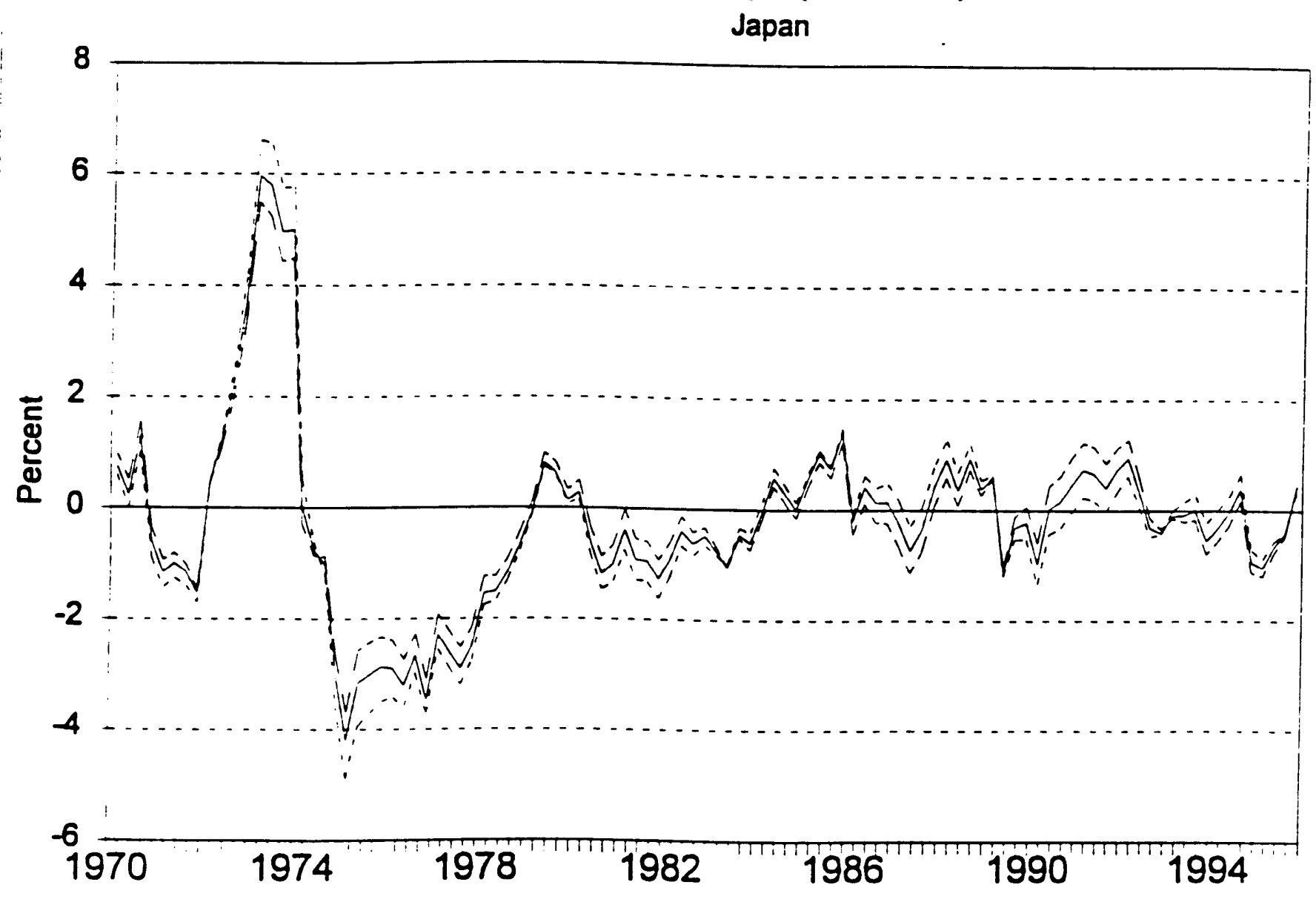

-- Alpha $=200-$ Alpha $=400 \ldots$ Alpha $=800$ 


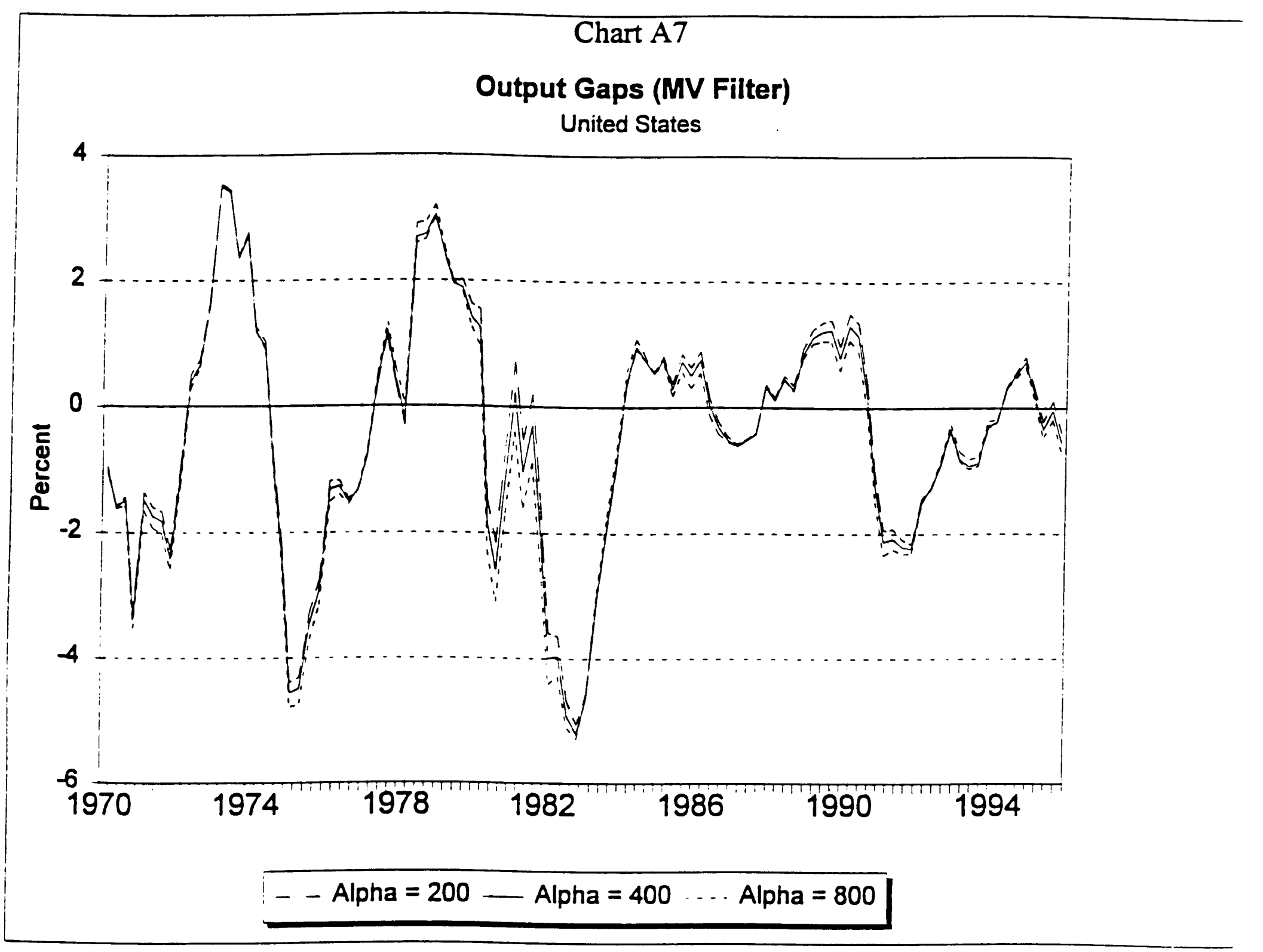




\section{References}

Adams, Charles and David T. Coe. "A Systems Approach to Estimating the Natural Rate of Unemployment and Potential Output for the United States." IMF Staff Papers 37 (June 1990):232-93.

Beveridge, Stephen and Charles R. Nelson. "A New Approach to Decomposition of Economic Time Series into Permanent and Transitory Components with Particular Attention to Measurement of the Business Cycle."' Journal of Monetary Economics 7 (March 1981):151-74.

Blanchard, Olivier and Danny Quah. "The Dynamic Effects of Aggregate Demand and Supply Disturbances." American Economic Review 79 (September 1989): 655-73.

Hodrick Robert J. and Edward C. Prescott. Post-War U.S. Business Cycles: An Empirical Investigation. Discussion Paper 451. Evanston, Il: Center for Mathematical Studies in Economics and Management Science, Northwestern University, 1980.

Kuttner, "Estimating Potential Output as a Latent Variable." Journal of Business and Economic Statistics 12:3 (July 1994).

Laxton, Douglas and Robert Tetlow. "A Simple Multivariate Filter for the Measurement of Potential Output." Bank of Canada Technical Report No. 59 (1992).

Laxton, Douglas, Kevin Shoom, and Robert Tetlow. "Should the change in the gap appear in the Phillips Curve?: Some Consequences of Mismeasuring Potential Output." Working Paper 92-1. Ottawa: Bank of Canada (January 1992).

OECD Economic Outlook, "Estimating Potential Output, Output Gaps, and Structural Budget Balances," 56, December 1994:31-37. 


\section{International Finance Discussion Papers}

IFDP

Number

561

560

559

558

557

556

555

554

553

552

551

550

549

548
Titles

Author(s)

$\underline{1996}$

$$
\text { Inflation-Adjusted Potential Output }
$$

The Management of Financial Risks at German

Nonfinancial Firms: The Case of Metallgesellschaft

Broad Money Demand and Financial Liberalization in Greece

Stockholding Behavior of U.S. Households: Evidence from the 1983-89 Survey of Consumer Finances

Firm Size and the Impact of Profit-Margin Uncertainty on Investment: Do Financing Constraints Play a Role?

Regulation and the Cost of Capital in Japan: A Case Study

The Sovereignty Option: The Quebec Referendum and Market Views on the Canadian Dollar

Real Exchange Rates and Inflation in Exchange-Rate Based Stabilizations: An Empirical Examination

Macroeconomic State Variables as Determinants of Asset Price Covariances

The Tequila Effect: Theory and Evidence from Argentina

The Accumulation of Human Capital: Alternative Methods and Why They Matter

Alternatives in Human Capital Accumulation: Implications for Economic Growth

More Evidence on the Link between Bank Health and Investment in Japan

The Syndrome of Exchange-Rate-Based Stabilization and the Uncertain Duration of Currency Pegs
Jane T. Haltmaier

Allen B. Frankel

David E. Palmer

Neil R. Ericsson

Sunil Sharma

Carol C. Bertaut

Vivek Ghosal

Prakash Loungani

John Ammer

Michael S. Gibson

Michael P. Leahy

Charles P. Thomas

Steven B. Kamin

John Ammer

Martín Uribe

Murat F. Iyigun

Ann L. Owen

Murat $F$. Iyigun

Ann L. Owen

Michael S. Gibson

Enrique G. Mendoza Martín Uribe

Please address requests for copies to International Finance Discussion Papers, Division of International Finance, Stop 24, Board of Governors of the Federal Reserve System, Washington, D.C. 20551 . 


\section{International Finance Discussion Papers}

IFDP

Number

Titles

1996

547 German Unification: What Have We Leamed from Multi-Country Models?

546 Returns to Scale in U.S. Production: Estimates and Implications

545 Mexico's Balance-of-Payments Crisis: A Chronicle of Death Foretold

$544 \quad$ The Twin Crises: The Causes of Banking and Balance-of-Payments Problems
High Real Interest Rates in the Aftermath of Disinflation: Is it a Lack of Credibility?

Precautionary Portfolio Behavior from a Life-Cycle Perspective

Using Options Prices to Infer PDF's for Asset Prices: An Application to Oil Prices During the Gulf Crisis

Monetary Policy in the End-Game to Exchange-Rate Based Stabilizations: The Case of Mexico

Comparing the Welfare Costs and the Initial Dynamics of Alternative Temporary Stabilization Policies

Long Memory in Inflation Expectations: Evidence from Intemational Financial Markets

Using Measures of Expectations to Identify the Effects of a Monetary Policy Shock

Regime Switching in the Dynamic Relationship between the Federal Funds Rate and Innovations in Nonborrowed Reserves

The Risks and Implications of Extemal Financial Shocks: Lessons from Mexico

Currency Crashes in Emerging Markets: An Empirical Treatment
Author(s)

Joseph E. Gagnon

Paul R. Masson

Warwick J. McKibbin

Susanto Basu

John G. Fernald

Guillermo A. Calvo

Graciela L. Kaminsky

Carmen M. Reinhart

Graciela L. Kaminsky

Leonardo Leiderman

Carol C. Bertaut

Michael Haliassos

William R. Melick

Charles P. Thomas

Steven B. Kamin

John H. Rogers

Martin Uribe

Joseph E. Gagnon

Allan D. Brunner

Chan Huh

Edwin M. Truman

Jeffrey A. Frankel

Andrew K. Rose 